Article

\title{
Exploration Potential of Fine-Fraction Heavy Mineral Concentrates from Till Using Automated Mineralogy: A Case Study from the Izok Lake $\mathrm{Cu}-\mathrm{Zn}-\mathrm{Pb}-\mathrm{Ag}$ VMS Deposit, Nunavut, Canada
}

\author{
H. Donald Lougheed ${ }^{1, *}$, M. Beth McClenaghan ${ }^{2}$, Dan Layton-Matthews ${ }^{1}$ and \\ Matthew Leybourne 1,3 (D) \\ 1 Queen's Facility for Isotope Research, Department of Geological Sciences and Geological Engineering, \\ Queen's University, 36 Union St., Kingston, ON K7L 3N6, Canada; dlayton@queensu.ca (D.L.-M.); \\ m.leybourne@queensu.ca (M.L.) \\ 2 Geological Survey of Canada, 601 Booth St., Ottawa, ON K1A 0E8, Canada; beth.mcclenaghan@canada.ca \\ 3 McDonald Institute, Canadian Particle Astrophysics Research Centre, Department of Physics, Engineering \\ Physics \& Astronomy, Queen's University, 64 Bader Lane, Kingston, ON K7L 3N6, Canada \\ * Correspondence: 5hdl@queensu.ca
}

Received: 15 February 2020; Accepted: 26 March 2020; Published: 30 March 2020

check for updates

\begin{abstract}
Exploration under thick glacial sediment cover is an important facet of modern mineral exploration in Canada and northern Europe. Till heavy mineral concentrate (HMC) indicator mineral methods are well established in exploration for diamonds, gold, and base metals in glaciated terrain. Traditional methods rely on visual examination of $>250 \mu \mathrm{m}$ HMC material, however this study applies modern automated mineralogical methods (mineral liberation analysis (MLA)) to investigate the finer $(<250 \mu \mathrm{m})$ fraction of till HMC. Automated mineralogy of finer material allows for rapid collection of precise compositional and morphological data from a large number $(10,000-100,000)$ of heavy mineral grains in a single sample. The Izok Lake volcanogenic massive sulfide (VMS) deposit, one of the largest undeveloped $\mathrm{Zn}-\mathrm{Cu}$ resources in North America, has a well-documented fan-shaped indicator mineral dispersal train and was used as a test site for this study. Axinite, a VMS indicator mineral difficult to identify optically in HMC, is identified in till samples up to $8 \mathrm{~km}$ down ice. Epidote and Fe-oxide minerals are identified, with concentrations peaking proximal to mineralization. Corundum and gahnite are intergrown in till samples immediately down ice of mineralization. Till samples also contain chalcopyrite and galena up to $8 \mathrm{~km}$ down ice of mineralization, an increase from $1.3 \mathrm{~km}$ for sulfide minerals in till previously reported for coarse HMC fractions. Some of these sulfide grains occur as inclusions within chemically and physically robust mineral grains and would not be identified visually in the coarse HMC visual counts. Best practices for epoxy mineral grain mounting and abundance reporting are presented along with the automated mineralogy of till samples down ice of the deposit.
\end{abstract}

Keywords: indicator minerals; heavy mineral concentrates; automated mineralogy; till sampling; VMS; MLA; Izok Lake

\section{Introduction}

Indicator mineral methods applied to sediment samples are important exploration tools in glaciated terrain for diamonds [1] and gold [2-5]. More recently, their potential to aid porphyry Cu [6-8], magmatic Ni-Cu-PGE [5,9], carbonate-hosted Pb-Zn [10] and volcanogenic massive sulfide (VMS) exploration [11] has been demonstrated. 
Using current sampling protocols, a large till or stream sediment sample (10-20 kg) is necessary to recover detectable and meaningful numbers of indicator mineral grains in a single sample [12]. Indicator minerals are recovered from these large samples at specialized commercial laboratories using a combination of sizing, magnetic and density concentration methods to reduce the volume of material into a non-ferromagnetic heavy mineral concentrate (HMC). The coarse fraction $(>250 \mu \mathrm{m}$, medium to coarse sand size) of the HMC is subsequently visually examined to identify and count indicator minerals using a binocular microscope [13]. These methods focus on the recovery of the coarser ( $>250 \mu \mathrm{m}$, medium to very coarse sand) mineral fraction of sediments because it is cost effective and relatively easy to recover and visually examine. The resulting HMC is composed of dense mineral grains (specific gravity (SG) >3.2) displaying varying levels of physical and chemical weathering, and the degree of abrasion and wear can be used to infer the transport distance of certain minerals [3]. Mineral associations can be observed in composite grains, while the degree of liberation of interlocked minerals can also serve as an indicator of mechanical weathering during transport.

Developments in rapid scanning electron microscopy (SEM) such as mineral liberation analysis (MLA, Hillsboro, OR, USA) or Quantitative Evaluation of Minerals by Scanning Electron Microscope (QEMSCAN ${ }^{\mathrm{TM}}$, Hillsboro, OR, USA) over the past 10 years make it possible to also examine and analyze the finer $(<250 \mu \mathrm{m})$ heavy mineral fraction of sediment samples using automated technologies [14]. Automated mineralogy provides the potential for the identification and utilization of additional indicator minerals that traditional visual examination of the $>250 \mu \mathrm{m}$ mineral fraction does not allow.

Volcanogenic massive sulfide (VMS) deposits are an important source of $\mathrm{Cu}, \mathrm{Pb}$ and $\mathrm{Zn}$ in Canada $[15,16]$. Thus, indicator mineral methods can be an important exploration method in Canada because much of the landscape is covered by glacial deposits. Metamorphism of massive or disseminated sulfide ore bodies results in coarsening of sulfide and alteration mineral grains as a result of recrystallization and grain boundary reduction. Indicator minerals commonly found in glacial dispersal trains extending from metamorphosed VMS deposits can include chalcopyrite, barite, gahnite, spinel-staurolite-sapphirine, kyanite-sillimanite, anthophyllite-orthopyroxene, spessartine, red epidote $(\mathrm{Mn})$, red rutile $(\mathrm{Cr})$, and loellingite [3,17]. Some of these minerals are soft and/or brittle, thus they do not survive glacial transport and deposition or subsequent post-glacial weathering as readily as more resistant phases. Chalcopyrite in glacial sediments is more resistant to weathering than other sulfide minerals and commonly forms dispersal patterns larger than those of other sulfides present in a deposit in greater abundance [3]. Oxide and silicate minerals are typically more physically and chemically robust than sulfide minerals and thus better survive glacial transport, deposition and subsequent postglacial weathering, and their dispersal fans can extend to hundreds of kilometers in length.

To investigate the potential application of MLA to indicator minerals of highly metamorphosed VMS deposits, the heavy mineral concentrates from till samples previously collected around the Izok Lake $\mathrm{Zn}-\mathrm{Cu}-\mathrm{Pb}-\mathrm{Ag}$ VMS deposit by the Geological Survey of Canada (GSC), Ottawa, ON, Canada $[11,18]$ were examined using MLA. Four till samples were selected for this study and all had been previously processed at the commercial laboratory Overburden Drilling Management Limited, Ottawa, ON, Canada, to prepare heavy HMC of the $<0.25 \mathrm{~mm}, 0.25-0.5 \mathrm{~mm}, 0.5-1.0 \mathrm{~mm}$ and 1.0-2.0 mm fractions. Hicken et al. [18] and McClenaghan et al. [11] reported on indicator minerals that were visually identified in the $0.25-2.0 \mathrm{~mm}$ HMC of the till samples. This study tested and evaluated the efficacy and efficiency of MLA to determine all minerals present in the $<250 \mu \mathrm{m}$ HMC fraction, as well as the key indicator minerals of VMS mineralization.

\subsection{Bedrock Geology of the Izok Lake Area}

The Izok Lake VMS deposit is located in the central Slave Province, Canada, a granitic-greenstone terrane comprising deformed and metamorphosed Archean rocks hosting the Yellowknife Supergroup, a package of 2.67-2.70 Ga metasedimentary and metavolcanic rocks [19]. The Yellowknife Supergroup is divided into the lower Point Lake Formation (a suite of mafic tholeiitic to felsic calc-alkaline metavolcanic rocks and derived metasedimentary rocks, part of the Banting Group) and the upper Contwoyto 
Formation (a series of iron formation-bearing greywacke turbidites) (Figure 1). These formations host numerous granitic plutons along with N-NW trending regional diabase dykes of the Helikian Mackenzie Swarm [20,21].

The deposit is hosted within the Izok Lake volcanic belt of the Point Lake Formation $[22,23]$ that forms an arcuate belt approximately $18 \mathrm{~km}$ long and 1 to $5 \mathrm{~km}$ wide [24]. The deposit is located near the stratigraphic top of this belt. To the south of Izok Lake, the belt strikes southwest and dips steeply to the southeast, whereas to the north it makes an abrupt shift to striking northwest and dipping steeply northeast. This abrupt shift in strike is the result of regional deformation, referred to as the Izok Lake antiform.

Rocks to the south of the deposit have been interpreted to be greenschist-facies conditions with a mineral assemblage of albite-epidote-chlorite, whereas rocks to the north are interpreted as upper amphibolite-sillimanite grade with a mineral assemblage of hornblende-cordierite-sillimanite [25]. The difference in metamorphic grade to the north and south was interpreted by Thomas [25] to be the result of two regional metamorphic facies, but this idea was challenged first by Morrison [22] and later by Nowak [26]. They suggested that the rocks in the region were affected by a single craton-wide, high-temperature, low-pressure event. This conclusion is supported by similarities between $\mathrm{P}-\mathrm{T}$ estimates from mineral assemblages at Izok Lake and other rocks from the Slave Craton [22], whereas the local variation in metamorphic mineral assemblages identified is attributed to variations in pre-metamorphic bulk rock composition brought about by varying degrees of hydrothermal alteration [26].

Nowak [26] related the variations in pre-metamorphic bulk rock composition to the different types and intensities of hydrothermal alteration associated with mineralization. His work calculated bulk rock compositions using detailed geochemical whole-rock analysis, and also by combining detailed modal mineral abundance data gathered by automated mineralogy (QEMSCAN) with compositional data gathered by electron microprobe analysis (EMPA). Nowak [26] used discrimination plots to compare data from Izok Lake to several unmetamorphosed to low-grade metamorphosed VMS deposits, and the bulk rock compositions of the mineral assemblages identified are consistent with those of the associated alteration haloes from the other sites.

Mineralized boulders containing upwards of 30\% Zn were discovered along the west and south shores of Izok Lake by Money and Heslop [27], and this initiated more detailed local exploration and the discovery of the Izok Lake deposit. The deposit was explored by several companies, including Minnova Corp., Inmet Mining, Wolfden Resources Corp., and the current property owner MMG [28]. The deposit consists mainly of galena, sphalerite, and chalcopyrite, with a variety of other less abundant ore minerals including covellite, digenite, electrum, and native silver $[22,23,27]$.

Izok Lake is a significant mineral resource, with total indicated and inferred resources of $14.8 \mathrm{Mt}$ grading $2.5 \% \mathrm{Cu}, 12.8 \% \mathrm{Zn}, 1.3 \% \mathrm{~Pb}$, and $71 \mathrm{~g} / \mathrm{t} \mathrm{Ag}$ within a group of five near-surface sulfide lenses (North, Northwest, Central West, Central East, and Inukshuk) [29], making it one of the largest undeveloped $\mathrm{Zn}-\mathrm{Cu}$ resources in North America [22]. The three westernmost of these lenses subcrop under Izok Lake. The five lenses are arranged with two northern lenses, two central lenses, and one peripheral lens (The Inukshuk lens). The two north lenses are lower grade than the two central lenses and both subcrop under Izok Lake. The North lens is small and located near the surface and is considered to be the remnant trough of a sulfide lens that was eroded by glacial activity. The two central lenses represent the majority of the deposit's metal endowment, being larger and richer in $\mathrm{Cu}$ than the two northern lenses, and of the two the central west lens subcrops under Izok Lake. The Inukshuk lens is the least defined of the five sulfide lenses, and does not appear to subcrop in the region [22]. 


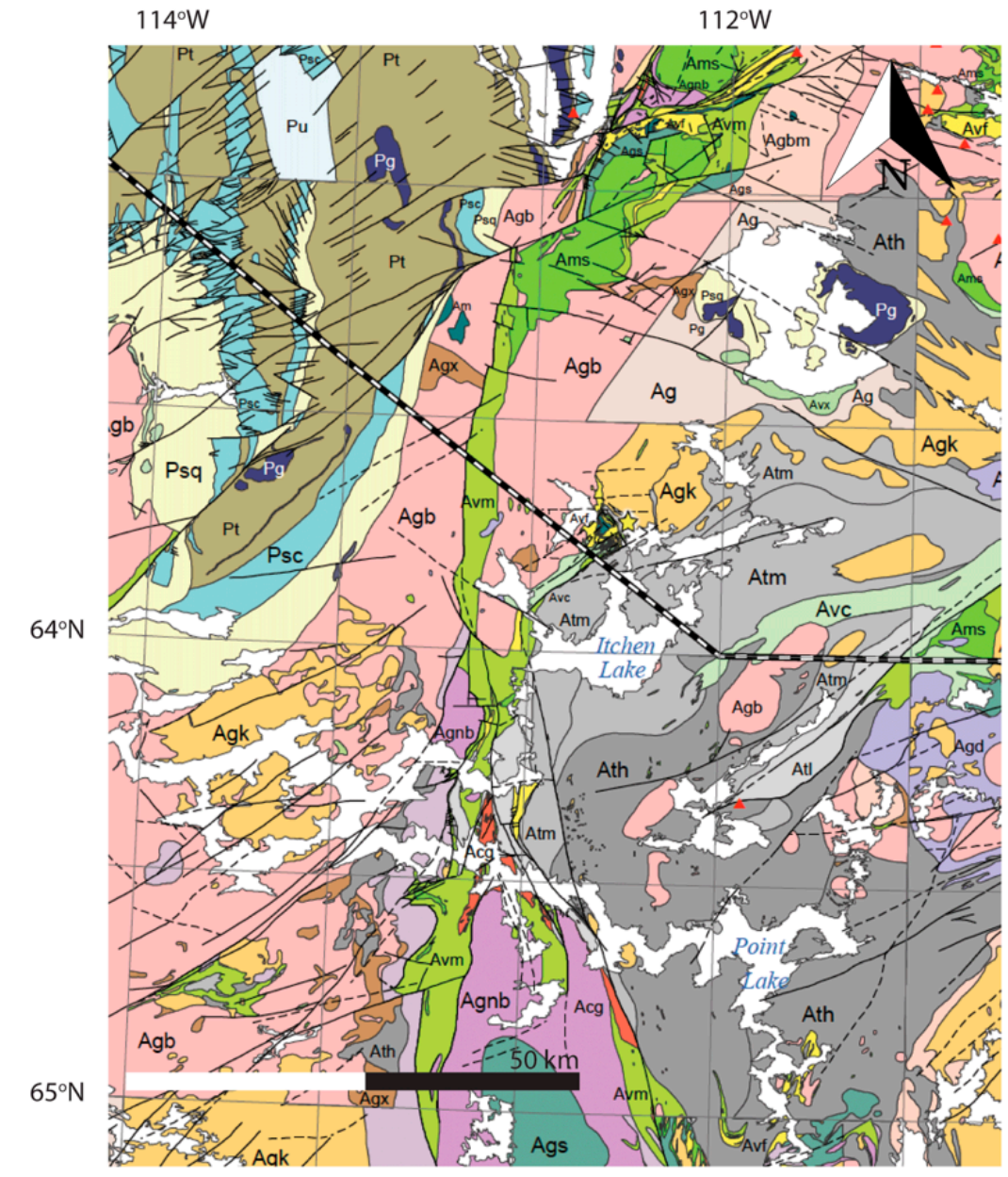

Proterozoic Map Legend

Pg Diabase - gabbro sills and or dykes; various ages

\begin{tabular}{|l|l}
\hline Pt & Paleoproterozoic foredeep facies; primary greywacke and pelite (turbidites) \\
\hline
\end{tabular}

Psc Paleoproterozoic shelf $(+/$-rift) facies dominated by carbonate rocks (dolomite, dololutute, stromatolites)

Psq Paleoproterozoic shelf alluvial $(+/$ - rift) facies dominated by argilitite, quartzite \& conglomerate with lesser carbonate Punsubdivided Proteroze
principal tectonic zones

Archean

Intrusive Rocks

$\mathrm{Ag}$ Granitoids - unsubdivided; includes intrusions with minimal published descriptions or which are not characteristic of

other subdivisions

Grantonds-2-mica or K-feldspar megacrystic, peegmatite mostly syn- to post-kinematic (ca. $2605-2580 \mathrm{Man}$ )

Agb Biotite +/- hormblende rich granitoids, mostly pre- to syn-kinematic (ca. 2625-2590 Ma); includes Unit Agbm

Agbm Biotite + + - homblende rich granitoids, mostly pre- to syn-kinematic (ca. $2625-2590 \mathrm{Ma}$ ) enhanced magnetic signature

Agx Granitoids with abundant supracrustal gabbro/gneiss xenoliths

Ams Mafic intrusions (gabbro, anorthosite, dionte) associated with volcanic rocks; various ages represented but mos Supracrustal Rocks

Keskarrah Formation

Acg Conglomerate - arenite- siltstone clastic sequence (mostly $2605 \mathrm{Ma}$ )

Contwoyto Formation

Atm Turbiditic wacke to mudstone - medium grade; knotted schists (andalusite + /or cordiente porphyroblasts)

A th Tubiditic wacke to mudstone - high grade to migmatitic (sillimanite-grade + / or anatectic melt phases) Banting Group

Avm Volcanic rocks monse to intermediate lavas, volcaniclastics, \& related intrusions

Avx Volcanic rocks - heterogeneous interlayered felsic to mafic lavas, volcaniclastics, \& related intrusions

Avc Volcaniclastic rocks - unsubdivided

Avf Volcanic rocks - felsic to intermediate lavas, volcaniclastics, \& related intrusions; local carbonate interbeds

Central Slave Basement Gneissic Complexes

Agnb Gneiss \& granitoid complex - heterogeneous; in part, with demonstrated or assumed "basement" ( $>2.8 \mathrm{Ga}$ components

Gneiss \& granitoid complex - heterogeneous and unsubdivided; massive to migmatitic and gneissic granitoids
various ages represented

Symbols

Kimberlites (approximate location)
Location of the Izok deposit

Figure 1. Geological map of the Point Lake belt, northwest Slave Province, Nunavut, Canada. The location of the Izok Lake deposit within the belt is indicated by the yellow star. Heavy black and white dashed line indicates the NWT-Nunavut border. Compiled using map data from Stubley and Irwin [30]. 
Within the region surrounding the Izok Lake deposit, rocks in the footwall of the deposit and to the north have been interpreted as a rhyolite protolith metamorphosed to upper amphibolite-sillimanite grade with characteristic mineral assemblages of hornblende, cordierite, and sillimanite. Hanging wall rocks are interpreted as meta-andesite (cordierite-biotite-epidote-garnet), aphyric meta-rhyolite (quartz-muscovite-sillimanite-garnet), and metagabbro (amphibole-plagioclase-biotite-garnet-magnetite). Gahnite (Zn-spinel) is a metamorphic mineral occurring in stringer-sulfide mineralized zones proximal to one of the deposit's five sulfide lenses. Gahnite was identified by Hicken et al. [18] and McClenaghan et al. [11] as a useful indicator mineral of mineralization at Izok Lake, present in a dispersal fan down ice of the deposit. In bedrock, gahnite is found in close association with quartz, feldspar, biotite, muscovite, sphalerite, chalcopyrite, and pyrrhotite [22,26,31].

\subsection{Surficial Geology}

The Izok Lake region was most recently glaciated during the Wisconsinan [32]. Regional surficial mapping in the Izok Lake region was carried out by Stea et al. [33], with large-scale ice flow reconstructions compiled by Dyke and Prest [34] and Dyke [35]. Recent ice flow indicator mapping in the region by Paulen et al. [36] built on the previous work to elucidate four ice flow phases that affected the region. Of these, an older southwest ice flow and younger northwest ice flow were determined to be responsible for the formation of most local glacial landforms and the palimpsest glacial transport of mineralized debris down ice $[11,18]$. These ice flows deposited a till cover that is relatively thin ( $<3 \mathrm{~m}$ thick) and consists mainly of silty sand till. The Izok Lake region is a permafrost terrain and, therefore, it is not practical to dig to appropriate till horizons by hand. All samples were collected at the surface from frost boils, small circular periglacial features formed by cryoturbation that bring till material from depth to surface [37].

The GSC carried out a reconnaissance-scale till geochemical survey in the Point Lake region, including the Izok Lake area, but geochemical analysis of the $<0.002 \mathrm{~mm}$ and $<0.063 \mathrm{~mm}$ till fractions did not indicate the presence of the mineralization at Izok Lake [38]. In 2009, a till geochemical survey was carried out around the Izok Lake deposit [17] along with a detailed bedrock and till indicator mineral survey. The $<63 \mu \mathrm{m}$ fraction of till, analyzed by aqua regia/inductively coupled plasma mass spectrometry (ICP-MS), yielded elevated values for $\mathrm{Zn}(<346 \mathrm{ppm}), \mathrm{Cu}(<322 \mathrm{ppm}), \mathrm{Pb}(<392 \mathrm{ppm})$, Fe (<1880 ppm), Ag (<1411 ppb), Cd (<1.36 ppm), Bi (<5.12 ppm), Hg (<247 ppb), Se (<0.5 ppm), In $(<0.28 \mathrm{ppm})$, and $\mathrm{Tl}(<0.20 \mathrm{ppm})$ up to $6 \mathrm{~km}$ down ice to the northwest [11]. Also in 2009, a gossan containing sphalerite and referred to as the West Iznogoudh (WIZ) showing (Figure 2; [27]) was sampled. Oviatt [39] reported elevated contents of $\mathrm{Zn}, \mathrm{Ag}, \mathrm{Cu}, \mathrm{Hg}$, and $\mathrm{Bi}$ in the $<63 \mu \mathrm{m}$ fraction of till collected in the vicinity of the showing.

In addition to the till geochemical samples, bulk (10-15 kg) till and bedrock $(1 \mathrm{~kg})$ samples were collected around the Izok Lake deposit, concentrated to produce HMC and the $>250 \mu \mathrm{m}$ size fraction was examined for indicator minerals. That study identified gahnite, staurolite, chalcopyrite, sphalerite, pyrrhotite, and pyrite as indicator minerals. Gahnite dispersal was identified to be the broadest and farthest down ice of all of the indicator minerals identified, extending more than $40 \mathrm{~km}$ to the northwest with an older component to the southwest $[11,18]$. Significant abundances of sulfide minerals (chalcopyrite, galena, sphalerite, pyrite) were identified in the coarse fraction of only the most proximal down ice till sample to mineralization. Axinite, a potential indicator of hydrothermal alteration, was identified in bedrock thin sections and HMC, but was not identified in till HMC due to its lack of distinguishing visual characteristics [18,31]. 


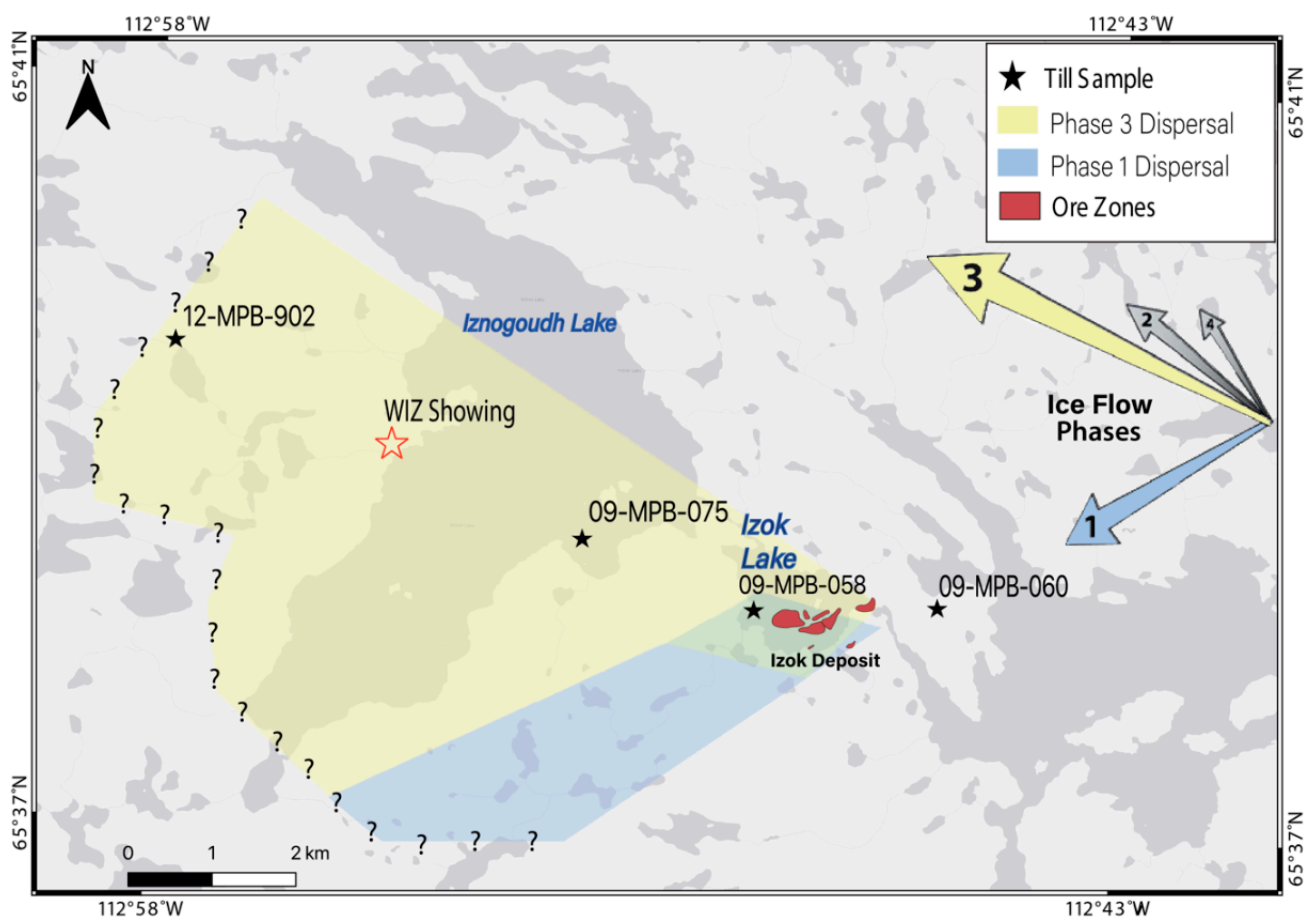

Figure 2. Location of the four till samples used in this study. Arrows indicate relative ice flow chronology $(1=$ oldest) and vigor (arrow width) of flow events. Colored polygons depict the glacial dispersal fan for gahnite in the non-ferromagnetic $250-500 \mu \mathrm{m}$ fraction of till heavy mineral concentrate (HMC), as interpreted by McClenaghan et al. [1]. Yellow polygon represents dispersal by the NW ice flow; blue represents dispersal by the older SW ice flow, and the question-marked border represents the terminal sampling distance beyond which data is not available.

\section{Materials and Methods}

Four till samples collected by Hicken et al. $[18,31]$ were chosen for use in this study. They were selected based on their locations relative to mineralization and the indicator minerals identified in their coarse fraction of HMC, in particular gahnite. The four sample locations are shown in Figure 2, along with the gahnite dispersal fan identified by McClenaghan et al. [11]. Sample 09-MPB-060, located $1 \mathrm{~km}$ up ice of mineralization, was the farthest-up ice sample available, and was chosen to represent background values compared to down ice sample locations. However, this up ice sample site is still within the hydrothermal alteration halo surrounding the Izok Lake deposit [22], and may not represent true regional background for certain alteration indicator minerals. Sample 09-MPB-058, located $500 \mathrm{~m}$ down ice (west) of mineralization, was the only sample with a significant abundance of sulfide indicator minerals identified in the coarse fraction [18,31]. It is the most proximal down ice sample chosen for this study. Sample 09-MPB-075, located $3 \mathrm{~km}$ down ice of mineralization, represents the intermediate down ice sample chosen for this study. Previous work identified gahnite in the coarse fraction HMC of these till samples. Sample 12-MPB-902, located $8 \mathrm{~km}$ down ice of mineralization, represents the most distal down ice sample chosen for this study.

\subsection{Preparation of Heavy Mineral Concentrate (HMC) in Previous Geological Survey of Canada (GSC) Study}

In 2009, the four GSC till samples were processed to recover >3.2 SG HMC at Overburden Drilling Management Limited (ODM), in Ottawa, ON, Canada. Density concentration was carried out using a combination of wet screening and shaking table, followed by heavy liquid separation at 3.2 SG, acid-washing, and ferro-magnetic separation to produce coarse $(>250 \mu \mathrm{m})$ non-ferromagnetic HMC (>3.2 SG) fraction. This fraction was visually examined, and indicator minerals were counted with results reported by Hicken [18] and McClenaghan et al. [11]. The archived byproduct of the sample 
processing was the non-ferromagnetic $<250 \mu \mathrm{m}$ fraction. It is this fraction that forms this basis of the study reported here (Table 1).

Table 1. Sample processing weights indicating the original mass of bulk till sample prior to heavy mineral concentrate (HMC) production, the individual mass of each size fraction following sieving of the $<250 \mu \mathrm{m} \mathrm{HMC}$, and the mass of $<250 \mu \mathrm{m}$ HMC lost during sieving.

\begin{tabular}{|c|c|c|c|c|c|}
\hline Sample & Original Mass (g) & Fraction $(\mu \mathrm{m})$ & Mass (g) & Mass Weighed (g) & Total Loss (g) \\
\hline \multirow{4}{*}{ 09-MPB-060 } & \multirow{4}{*}{16.637} & $185-250$ & 2.668 & \multirow{4}{*}{16.544} & \multirow{4}{*}{0.093} \\
\hline & & $125-185$ & 5.145 & & \\
\hline & & $64-125$ & 6.624 & & \\
\hline & & $<64$ & 2.107 & & \\
\hline \multirow{4}{*}{ 09-MPB-058 } & \multirow{4}{*}{29.223} & $185-250$ & 3.426 & \multirow{4}{*}{29.124} & \multirow{5}{*}{0.099} \\
\hline & & $125-185$ & 7.060 & & \\
\hline & & $64-125$ & 12.064 & & \\
\hline & & $<64$ & 6.574 & & \\
\hline \multirow{4}{*}{ 09-MPB-075 } & \multirow{4}{*}{22.933} & $185-250$ & 3.132 & & \\
\hline & & $125-185$ & 5.959 & \multirow{3}{*}{22.848} & \multirow{3}{*}{0.085} \\
\hline & & $64-125$ & 9.584 & & \\
\hline & & $<64$ & 4.173 & & \\
\hline \multirow{4}{*}{ 12-MPB-902 } & \multirow{4}{*}{22.769} & $185-250$ & 2.949 & \multirow{4}{*}{22.679} & \multirow{4}{*}{0.090} \\
\hline & & $125-185$ & 4.814 & & \\
\hline & & $64-125$ & 9.716 & & \\
\hline & & $<64$ & 5.200 & & \\
\hline
\end{tabular}

\subsection{Sieving Methods}

The $<250 \mu \mathrm{m}$ HMC fraction of the four till samples was dry-sieved at the Queen's University Facility for Isotope Research (QFIR, Kingston, ON, Canada) into four smaller size fractions: (1) 185-250 $\mu \mathrm{m}$, (2) $125-185 \mu \mathrm{m}$, (3) $64-125 \mu \mathrm{m}$, and (4) $<64 \mu \mathrm{m}$. The sieving was carried out using single-use, nylon-screened sieves following the procedures developed by Lougheed et al. [40]. Table 1 contains the masses of $<250 \mu \mathrm{m}$ HMC prior to sieving, the masses of each resultant size fraction, and the mass loss of HMC material as a result of sieving.

\subsection{Epoxy Mounting of Mineral Grains}

The grain mounting method used in this study was modified after Blaskovich [41]. In our study, the entire mass of each of the 16 subsamples was mixed with vacuum-evacuated epoxy and poured into a $2.54 \mathrm{~cm}$ diameter plastic ring mold. Each ring mold was immediately placed into a vacuum chamber under full vacuum for $5 \mathrm{~min}$. Vacuum impregnation eliminated air bubbles from liquid epoxy and drew epoxy into void spaces in mineral grains, maximizing the adhesion between epoxy and grains [42]. Following removal from the vacuum chamber, the mounts were allowed to cure for $24 \mathrm{~h}$. The resulting grain mount was trimmed and vertically quartered using a Raytech Jemsaw 45 (Raytech Industries, Middletown, CT, USA) fitted with a diamond-impregnated blade. One quarter of each mount was archived. The other three quarter-pieces were remounted into a single plastic ring mold and set with epoxy (Figure 3) and cured for $12 \mathrm{~h}$. Thus, one new epoxy mount containing three quarter slabs was prepared for each of the 16 subsamples. After polishing to $1 \mu \mathrm{m}$, these three slabs in the secondary mount were used for MLA analysis and examination of any settling effects or gradients that developed during mixing with epoxy and curing of the primary mount. Following polishing, the mounts were carbon coated using a Denton Vacuum Desk V carbon-coater (Denton Vacuum LLC, Moorestown, NJ, USA).

Grain mount preparation took $\sim 30 \mathrm{~min}$, followed by $12 \mathrm{~h}$ of curing time. Several samples were prepared simultaneously, with the limiting factor being the number of mounts that can be placed in the vacuum chamber. 


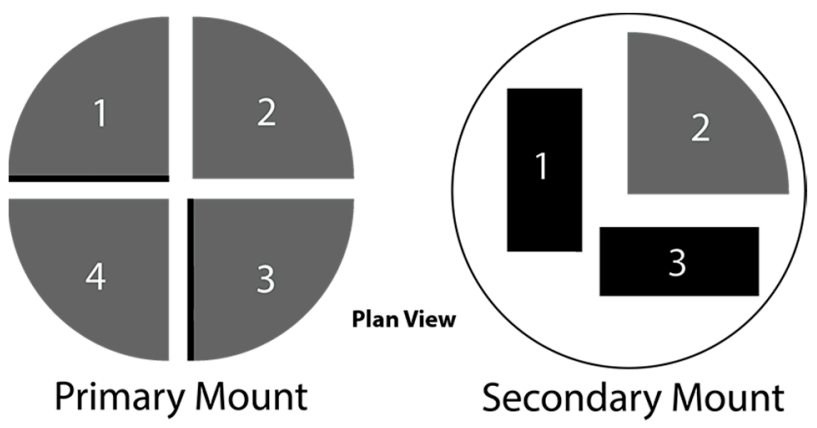

Figure 3. Mounting schematic displaying the basal surface of the two mounting stages. The primary grain mount was quartered, and three quarters were reoriented and made into a second mount to display one basal surface and two cross-sectional surfaces for analysis. Cross-sectional surfaces are indicated by the black grey bar in left pane of figure.

\subsection{Automated Mineralogy}

MLA is an automated mineralogy software package used in tandem with a field-emission gun scanning electron microscope equipped with electron dispersive spectrometer (EDS) detectors (FEG-SEM-EDS). The software uses high-resolution backscatter emission (BSE) images, image analysis, and elemental chemistry from EDS to create a mosaic image of an epoxy grain mount. The MLA software (version 3.1.4.686, FEI, Hillsboro, OR, USA) delineates grain boundaries based on BSE brightness contrast and subsequently collects a full X-ray spectrum (EDS) at the geometric center of each grain, comparing this to an established EDS mineral library assembled by the user, in order to identify the mineral [43]. The classified grains are subsequently combined into a false-color mineral image, and the program can quickly calculate for each grain, its size, mineral associations (occurrence and interlocking), particle properties (roundness, area, shape), and mineral liberation [44].

Carbon-coated grain mounts were analyzed using XBSE mode on a FEI Quanta 650 FEG SEM (Thermo Fisher Scientific, Waltham, MA, USA) operating under high vacuum at QFIR. The XBSE measurement mode collects a BSE image of each frame and uses variances in grey-level to define phase boundaries on a sample surface. This is followed by collection of a single EDS spot analysis at the calculated centroid of each identified phase. Operating conditions included a beam current of $10 \mathrm{nA}$, an accelerating voltage of $25 \mathrm{kV}$, and a spot size of 6 . Backscattered electron image brightness and contrast were standardized to a gold $(\mathrm{Au})$ imaging standard. Minimum feature size for image detection and minimum grain size for EDS analysis were both set to $4 \mu \mathrm{m}$. Magnification was set to $250 \times$ with a resolution of 1000 , resulting in a pixel size of $2.14 \mu \mathrm{m}$ and a horizontal field width of $2.14 \mathrm{~mm}$. Each basal quarter contained between 75 and 210 frames for analysis, whereas each vertical section contained between 100 and 200 frames. Analysis of a single grain mount took between $35 \mathrm{~min}$ and $2.5 \mathrm{~h}$, depending on the dimensions of the vertical slabs and the number of particles to analyze (Figure 3, slabs 1 and 3). Basal sections (Figure 3, slab 2) contain between 5000 and 50,000 particles.

Post-processing was performed using MLA Image Processing and Dataview, product version 3.1.4.686. Areas affected by charging effects were removed from the false-color map of each grain mount and each grain was classified using a mineral reference library constructed from spectra collected from the FEI reference library, augmented by spectra gathered manually over several years at QFIR.

Quality control evaluation of mineral identification, grain abundance analysis, and MLA error was carried out on one secondary mount of the 185-250 $\mu \mathrm{m}$ fraction and one of the $<64 \mu \mathrm{m}$ fraction. Both mounts were evaluated by performing a duplicate scan on a sub-section of each mount. Two scans were performed so that the difference in generated modal mineralogy data could be evaluated between scans of the same area under identical operating conditions, within the same scanning routine. After this scanning routine was completed, the two mounts were left in the machine and it underwent routine in-house calibration. Keeping the mounts inside the machine ensured that their orientation would not change. Following calibration, a second scanning routine was performed using the same settings as 
the first routine. This second scanning routine allowed for the evaluation of differences in generated modal mineralogy data prior to, and immediately following, routine calibration.

The time needed to complete an MLA scan varied depending on the operating parameters and the number of particles being analyzed. In general, decreasing particle size (and subsequently increasing particle abundance) increased the analysis time. Preparation of the mineral reference library was tailored to the needs of the study and the minerals/elements of interest, whereas the post-processing of data and generation of false-color grain maps and mineral abundance tables is a relatively routine process.

\section{Results}

\subsection{Grain Mount Density Gradients}

Grains on each epoxy grain mount were classified into three false colors according to their density; red $(>4.25 \mathrm{SG})$ for the heaviest $1 / 3$ of minerals in the mineral reference library, and green (3.24-4.25 SG) and black $(<3.24 \mathrm{SG})$ representing intermediate- and light-density minerals, respectively (Figure 4$)$. This classification was done to determine if any settling had affected the grains during preparation of the epoxy mounts. Heavy minerals (red) were more abundant in the bottom of the vertical slabs 1 and 3 from the primary mounts. The number of grains was also highest in the bottom $1 / 3$ of slabs 1 and 3 . In contrast, the basal surface of the primary mount (slab 2) contained a higher relative abundance of heavy minerals to lighter minerals, as well as a higher overall abundance of grains when compared to the vertical slab surfaces. This contrast between slab 1 and 3 versus slab 2 was observed in all secondary mounts for all till samples, for all size fractions examined. The differences between slabs 1 and 3 versus slab 2 were interpreted to be a settling gradient from top to bottom that formed after the grains were stirred into the epoxy during preparation of the primary mount.

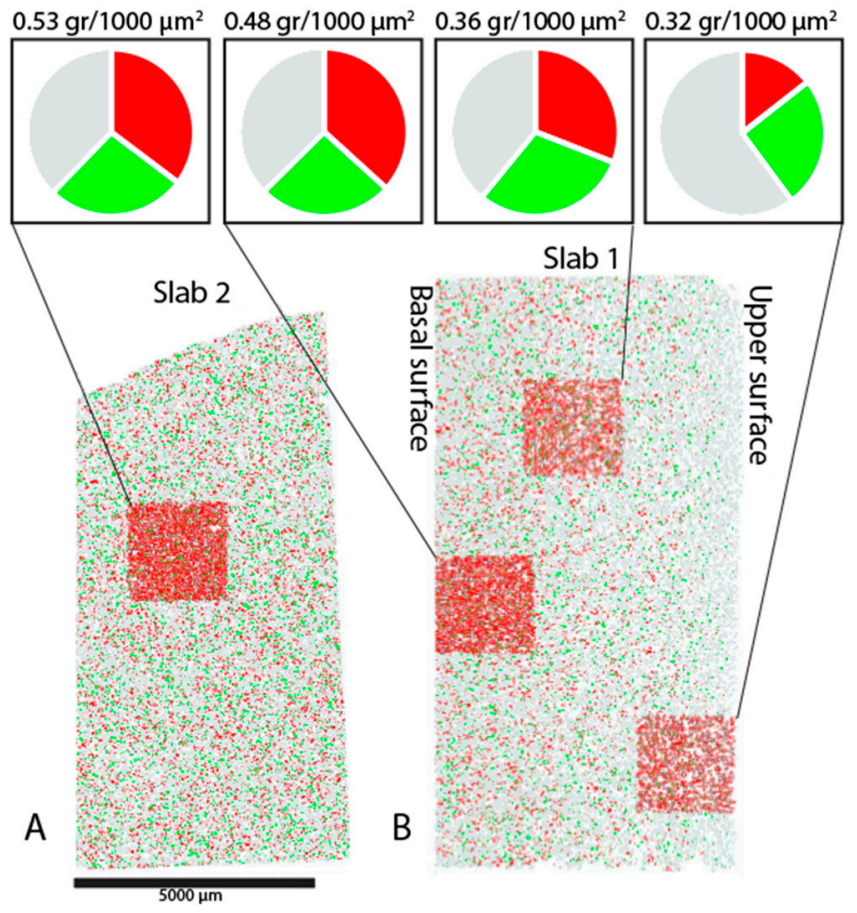

Figure 4. False-color grain maps of: (A) a portion of the slab 2 basal surface of a HMC epoxy grain mount, and (B) the entire slab 1 vertical cross-sectional surface of a HMC epoxy grain mount. Particle abundance per unit area and the relative abundance of heavy (red), intermediate (green) and light (grey) are depicted in the pie charts above for each red-shaded area. Three sections were analyzed on the vertical slabs and they display variations in particle abundance with depth through the slab. 


\subsection{Mineral Liberation Analysis (MLA) Error Estimation}

Modal mineralogy tables were generated for a portion of basal slab 2 from two different secondary mounts (one of the 185-250 $\mu \mathrm{m}$ fraction and one of the $<64 \mu \mathrm{m}$ fraction) for the duplicate MLA runs (before and after calibration). The absolute difference between the values generated by each scanning routine (in area percentage) was calculated for each mineral identified. The absolute difference was divided by the mean of the two area percentage values to prevent bias between minerals found in very low or very high abundances, and then divided by 2 to give an approximation of the percentage error above or below that mean value.

Values were calculated for successive scans of the same area, within the same scanning routine ("run"). This produced four "in-run" error comparison values, one for each of the two size fractions examined in the run before and the run following gun alignment calibration. In addition to the four in-run values, 8 "out-run" values were computed by comparing all possible permutations of before- and after-calibration scans for each of the two size fractions examined. Table 2 details the resulting in-run error values (before and after calibration) and the out-run error values for several indicator minerals.

Table 2. Calculated error between two identical MLA sample runs, before and after routine gun alignment calibration, for two size fractions of polished HMC grain mount. Out-run error is calculated using all runs, regardless of pre- or post-calibration.

\begin{tabular}{ccccc}
\hline \multicolumn{5}{c}{ Pre-Calibration } \\
Mineral & Scan 1 (area\%) & Scan 2 (area \%) & In-Run Error & Out-Run Error (avg.) \\
\hline Axinite & 0.0101 & 0.0073 & 0.1598 & 0.6806 \\
Epidote & 3.9529 & 3.8394 & 0.0146 & 0.0073 \\
Corundum & 0.0250 & 0.0251 & 0.0016 & 0.0042 \\
Hematite & 1.8558 & 1.8207 & 0.0095 & 0.0048 \\
Gahnite & 0.1110 & 0.1286 & 0.0735 & 0.0420 \\
Staurolite & 1.0410 & 1.0180 & 0.0112 & 0.0056 \\
\hline \multicolumn{5}{c}{ Post-Calibration } \\
Mineral & Scan $\mathbf{1}$ (area\%) & Scan 2 (area \%) & In-Run Error & \\
Axinite & 0.0026 & 0.0008 & 0.5246 & \\
Epidote & 3.9400 & 3.8814 & 0.0075 & \\
Corundum & 0.0248 & 0.0249 & 0.0023 & \\
Hematite & 1.8324 & 1.8428 & 0.0028 & \\
Gahnite & 0.1100 & 0.1096 & 0.0016 & \\
Staurolite & 1.0273 & 1.0276 & 0.0002 & \\
\hline
\end{tabular}

The identification of minerals using EDS requires the identification of peaks in EDS spectra, with the $x$-axis location of a peak representing one of the energy emissions of the element of interest and the area of the peak (PB-ZAF corrected) reflecting the relative abundance of that element. The method is therefore semi-quantitative, and a fully quantitative technique like wavelength-dispersive spectroscopy (WDS) is required to obtain precise measures of elemental abundance in a mineral. The semi-quantitative nature of automated mineralogy (EDS) analysis makes it difficult to discern between minerals with similar composition or highly variable stoichiometry. Conversely, automated mineralogy systems will excel at identifying minerals containing rare elements like $\mathrm{U}$ or $\mathrm{Zr}$, or minerals with distinct, simple spectra like many sulfide minerals [45]. Certain minerals were found consistently to represent outlier values. These minerals include garnets, pyroxenes, and other complex silicates, including axinite.

\subsection{Modal Mineralogy}

The basal slab 2 surface had the highest number of grains per unit area and highest proportion of the heaviest minerals for each sample. We deemed the basal slab 2 the most appropriate for use in the rest of the study and, therefore, mineralogy data are reported only for the slab 2 portion of each of the 16 secondary mounts. 
Several reporting metrics can be generated by automated mineralogical software packages, including volume percentage (vol. \%), weight percentage (wt. \%), grain count, and area percentage. The calculation of 3D vol. \% values from a $2 \mathrm{D}$ surface requires the generalization of grain volume as a sphere or ellipse using the length of the long axis present on the polished grain surface [43]. This is a powerful tool for many applications of automated mineralogy as it allows a user to establish a "grade" for a sample, when mineral chemistry data is combined with the resultant volume from MLA.

Simandl et al. [46] found a high coefficient of determination $\left(R^{2}=0.90\right)$ between the wt. \% estimation of $\mathrm{Nb}$-bearing minerals using QEMSCAN ${ }^{\mathrm{TM}}$ and $\mathrm{Nb}$ content determined by X-ray fluorescence (XRF), and a similarly high $\mathrm{R}^{2}$ value for the abundance of monazite with $(\Sigma \mathrm{La}, \mathrm{Ce}, \mathrm{Pr}, \mathrm{Nd})$ values obtained from borate fusion/nitric acid digestion/ICP-MS. However, the elements observed are not commonly present in a wide range of minerals. The method of determining wt. \% within automated mineralogy software packages assumes either perfect mineral stoichiometry or requires mineral chemistry data (e.g., by electron microprobe) and, therefore, wt. \% values are not appropriate for reporting the abundance of most till minerals, which have variable sources and stoichiometry, or where the elements of interest are commonly found in multiple mineral phases. Likewise, volume percentages do not enrich the interpretation of mineral abundance used in indicator mineral exploration and, therefore, area percentage (which both volume percentage and weight percentage are derived from) is the most appropriate reporting metric for till indicator mineral studies.

Although grain counts are an intuitive metric for understanding indicator mineral abundance and are more easily related to traditional visual grain counts for the $>250 \mu \mathrm{m} \mathrm{HMC}$, there is still a small amount of uncertainty introduced by the MLA software when it defines and separates grain boundaries. Area percentage is calculated by dividing the number of pixels assigned to a particular mineral value by the total number of pixels measured. This calculation supplies a metric that, although less intuitive than grain counts, represents a more precise quantitative measure.

Area percentage can be used in tandem with the number of grains to discern information about the occurrence of indicator minerals that would not be observed from either metric alone. Low grain counts with correspondingly high relative area percentage values suggest that a mineral is present as discrete whole grains (Figure 5). High grain counts combined with low area percentage values suggest that a mineral is present as high numbers of smaller grains or disseminated inclusions in other mineral grains. These conclusions must be confirmed by observing the mineral in a false-color MLA grain map. When using grain counts it is important to normalize values to allow for comparison between samples containing varying numbers of grains. Hulkki et al. [47] used two methods for normalizing grain count data, with their disaggregated bedrock samples being normalized using the equation:

(Number of a specific indicator mineral grain in a sample/ Total number of minerals grains in a sample) $\times 1000$

This ratio accommodates the varying number of grains analyzed between subsamples. The stream sediment grain counts of Hulkki et al. [47] were normalized to a $1 \mathrm{~kg}$ processed sample weight, although the authors noted that given the extremely low abundance of the $\mathrm{Cu}$ minerals of interest, the normalized values were very close to the numbers of observed mineral grains.

Values in this study were normalized using the same method as the bedrock samples described above. Normalizing to total processed sample weight does not consider the varying numbers of grains analyzed between the different size fractions studied, which can range between tens of thousands of grains on $185-250 \mu \mathrm{m}$ sample mounts to hundreds of thousands on $<64 \mu \mathrm{m}$ sample mounts. Normalizing to indicator grains/1000 grains allows for comparison of abundance values between samples, and between different size fractions of the same sample. 


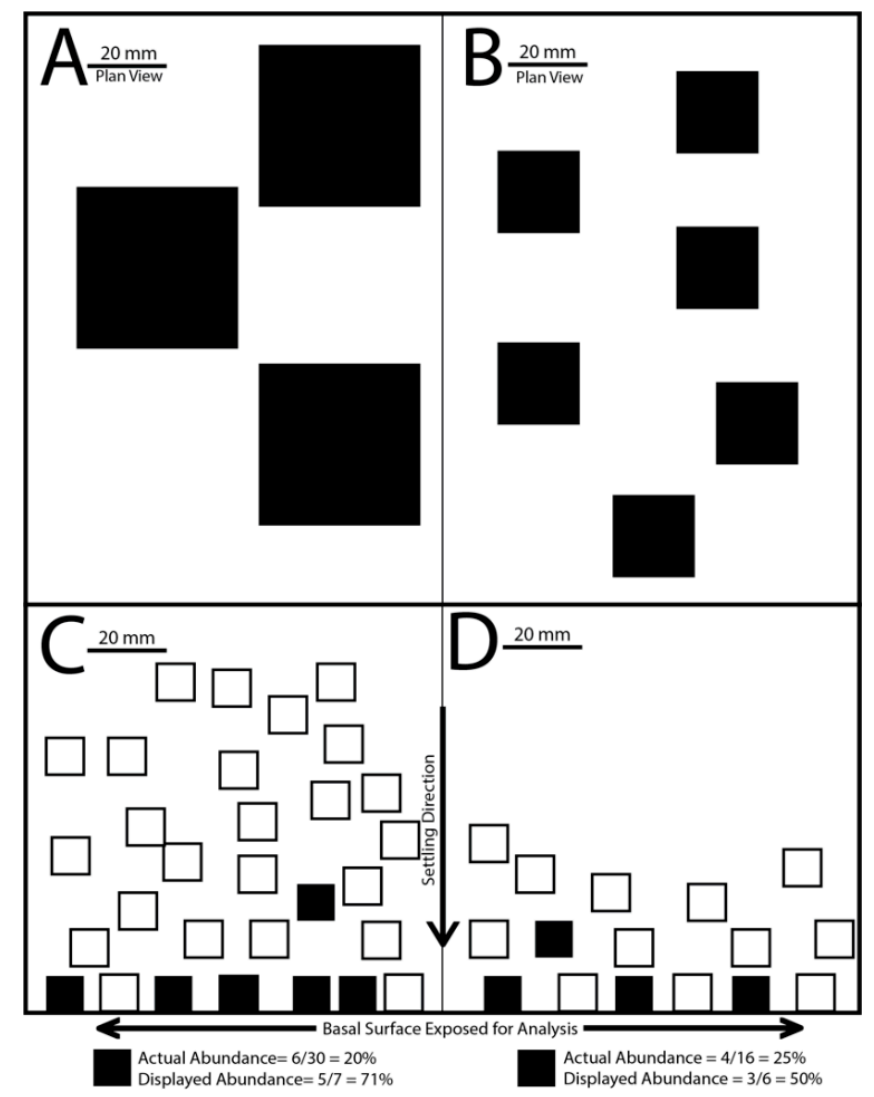

Figure 5. A,B conceptual view of the basal surface of epoxy grain mounts: (A) three large heavy (black) mineral grains; (B) six small heavy (black) mineral grains. The area (\%) values for heavy grains on mounts $\mathrm{A}$ and $\mathrm{B}$ are identical even though mount $\mathrm{A}$ contains half as many grains as mount $\mathrm{B}$. C,D conceptual cross section view through epoxy grain mounts: $(C)$ grain mount containing a greater total number of grains (30) than mount $D$, with four black grains out of a total of seven grains exposed on the basal surface; (D) grain mount containing a smaller total number of grains (16) than mount $C$ with three black grains out of a total of six grains exposed on the basal surface The actual abundance of heavy (black) grains per total grains mounted in epoxy is lower in mount C (5 out of 30 grains) than in mount D, but due to the preferential settling of heavier minerals through the curing epoxy, the displayed abundance on the polished basal surface is higher in mount C (71\%) than D (50\%).

The indicator mineral abundances for each indicator mineral for each slab 2 are reported in two different ways (Tables 3 and 4): (1) number of indicator grains normalized to 1000 grains, and (2) area percentage.

Minerals in the four size fractions of the four till samples are dominated by calcic amphibole, ilmenite, and almandine. Minerals present in lesser abundance include epidote, chlorite, biotite, titanite, rutile, and assorted Fe-oxide minerals (Figure 6). Quartz and albite, both less dense than the 3.2 SG heavy liquid used to process the original till samples, were found in high abundances in all samples, primarily as parts of composite particles containing other, denser minerals. Abundances increased with decreasing particle size for the following minerals: ilmenite, almandine, epidote, rutile, titanite, apatite, zircon, and monazite. Other minerals decreased in abundance with decreasing particle size: quartz, chlorite, and biotite. 
Table 3. Abundance of ore indicator minerals in four till sample up- and down ice of the Izok Lake volcanogenic massive sulfide (VMS) deposit. Mineral abundance data are reported in two ways: (1) number of indicator mineral grains per total grains, normalized to 1000 grains; (2) minerals by 2-dimensional percentage area they take up on the polished mount surface. Values for $0.25-0.50 \mu \mathrm{m}$ material are from the heavy mineral fraction of the same sample obtained by visual grain picking that have been normalized to a $10 \mathrm{~kg}$ of sample mass (data from Hicken et al. [2]).

\begin{tabular}{|c|c|c|c|c|c|c|c|c|c|c|}
\hline \multirow{2}{*}{ Sample } & \multirow{2}{*}{$\begin{array}{c}\text { Location } \\
\text { Relative to } \\
\text { Mineralization }\end{array}$} & \multirow{2}{*}{$\begin{array}{l}\text { Size Fraction } \\
(\mathrm{mm})\end{array}$} & \multicolumn{2}{|c|}{ Chalcopyrite } & \multicolumn{2}{|c|}{ Galena } & \multicolumn{2}{|c|}{ Pyrite } & \multicolumn{2}{|c|}{ Sphalerite } \\
\hline & & & Grains/Total ** & Area (\%) & Grains/Total ** & Area (\%) & Grains/Total ** & Area (\%) & Grains/Total ** & Area (\%) \\
\hline \multirow{5}{*}{ 09-MPB-060 } & \multirow{5}{*}{$1 \mathrm{~km}$ up ice } & $0.185-0.250$ & 0.00 & 0.0000 & 0.07 & 0.0001 & 0.51 & 0.0001 & 0.00 & 0.0000 \\
\hline & & $0.125-0.185$ & 0.00 & 0.0000 & 0.00 & 0.0000 & 0.24 & 0.0009 & 0.00 & 0.0000 \\
\hline & & $0.064-0.125$ & 0.00 & 0.0000 & 0.00 & 0.0000 & 0.40 & 0.0015 & 0.00 & 0.0000 \\
\hline & & $<0.064$ & 0.02 & 0.0001 & 0.00 & 0.0000 & 0.06 & 0.0014 & 0.00 & 0.0000 \\
\hline & & $0.250-0.500$ * & 0.00 & ND & 0.00 & ND & 0.00 & ND & 0.00 & ND \\
\hline \multirow{5}{*}{ 09-MPB-058 } & \multirow{5}{*}{$0.5 \mathrm{~km}$ down ice } & $0.185-0.250$ & 0.40 & 0.0006 & 0.40 & 0.0002 & 2.50 & 0.2117 & 8.09 & 0.8045 \\
\hline & & $0.125-0.185$ & 0.27 & 0.0177 & 0.09 & 0.0001 & 2.41 & 0.1592 & 1.50 & 0.4314 \\
\hline & & $0.064-0.125$ & 0.21 & 0.0010 & 0.03 & 0.0001 & 1.11 & 0.0966 & 1.14 & 0.1523 \\
\hline & & $<0.064$ & 0.07 & 0.0044 & 0.00 & 0.0000 & 0.25 & 0.0151 & 0.60 & 0.0710 \\
\hline & & $0.250-0.500$ * & 9.00 & ND & 0.00 & ND & 339.00 & ND & 1271.00 & ND \\
\hline \multirow{5}{*}{ 09-MPB-075 } & \multirow{5}{*}{$2.5 \mathrm{~km}$ down ice } & $0.185-0.250$ & 0.05 & 0.0002 & 0.29 & 0.0004 & 0.49 & 0.0019 & 0.00 & 0.0000 \\
\hline & & $0.125-0.185$ & 0.15 & 0.0004 & 0.00 & 0.0000 & 0.19 & 0.0012 & 0.00 & 0.0000 \\
\hline & & $0.064-0.125$ & 0.00 & 0.0000 & 0.09 & 0.0001 & 0.12 & 0.0011 & 0.00 & 0.0000 \\
\hline & & $<0.064$ & 0.06 & 0.0001 & 0.00 & 0.0000 & 0.17 & 0.0017 & 0.00 & 0.0000 \\
\hline & & $0.250-0.500$ * & 0.00 & ND & 0.00 & ND & 0.00 & ND & 0.00 & ND \\
\hline \multirow{5}{*}{ 12-МРB-902 } & \multirow{5}{*}{$8 \mathrm{~km}$ down ice } & $0.185-0.250$ & 0.09 & 0.0001 & 0.22 & 0.0006 & 0.26 & 0.0007 & 0.00 & 0.0000 \\
\hline & & $0.125-0.185$ & 0.12 & 0.0001 & 0.00 & 0.0000 & 0.40 & 0.0013 & 0.08 & 0.0001 \\
\hline & & $0.064-0.125$ & 0.05 & 0.0000 & 0.03 & 0.0004 & 0.08 & 0.0004 & 0.00 & 0.0000 \\
\hline & & $<0.064$ & 0.03 & 0.0000 & 0.00 & 0.0000 & 0.07 & 0.0004 & 0.03 & 0.0001 \\
\hline & & $0.250-0.500 *$ & 0.00 & ND & 0 & ND & 0 & ND & 0 & ND \\
\hline
\end{tabular}

${ }^{*}$ Grain Count, data from Hicken et al. [2] ${ }^{* *}$ Normalized to 1000 grains; ND = not determined. 
Table 4. Abundance of alteration indicator minerals in four till sample up- and down ice of the Izok Lake VMS deposit. Mineral abundance data are reported in two different ways: (1) number of indicator mineral grains per 1000 grains; (2) minerals by 2-dimensional percentage area they take up on the polished mount surface. Grey-shaded values are grain counts from the coarse $(250$ to $500 \mu \mathrm{m})$ heavy mineral fraction of the same sample obtained by visual grain picking that have been normalized to a $10 \mathrm{~kg}$ of sample mass (data from Hicken et al. [2]).

\begin{tabular}{|c|c|c|c|c|c|c|c|c|c|c|}
\hline \multirow{2}{*}{ Sample } & \multirow{2}{*}{$\begin{array}{c}\text { Location } \\
\text { Relative to } \\
\text { Mineralization }\end{array}$} & \multirow{2}{*}{$\begin{array}{l}\text { Size Fraction } \\
(\mathrm{mm})\end{array}$} & \multicolumn{2}{|c|}{ Corundum } & \multicolumn{2}{|c|}{ Epidote } & \multicolumn{2}{|c|}{ Staurolite } & \multicolumn{2}{|c|}{ Gahnite } \\
\hline & & & Grains/Total ** & Area (\%) & Grains/Total ** & Area (\%) & Grains/Total ** & Area (\%) & Grains/Total ** & Area (\%) \\
\hline \multirow{5}{*}{ 09-МРВ-060 } & \multirow{5}{*}{$1 \mathrm{~km}$ up ice } & $0.185-0.250$ & 0.14 & 0.0024 & 21.23 & 5.4712 & 13.57 & 3.1242 & 0.00 & 0.0000 \\
\hline & & $0.125-0.185$ & 0.69 & 0.0335 & 29.28 & 6.0791 & 11.41 & 2.6086 & 0.08 & 0.0283 \\
\hline & & $0.064-0.125$ & 0.61 & 0.0553 & 48.06 & 8.9677 & 12.73 & 2.2661 & 0.03 & 0.0000 \\
\hline & & $<0.064$ & 0.81 & 0.0366 & 47.26 & 7.2992 & 13.99 & 1.9695 & 0.10 & 0.0064 \\
\hline & & $0.250-0.500$ * & & ND & $590 * * *$ & ND & 3061.00 & ND & 0.00 & ND \\
\hline \multirow{5}{*}{ 09-МРВ-058 } & \multirow{5}{*}{$0.5 \mathrm{~km}$ down ice } & $0.185-0.250$ & 3.59 & 0.177 & 26.65 & 6.7352 & 12.68 & 2.0104 & 2.30 & 0.3724 \\
\hline & & $0.125-0.185$ & 1 & 0.0582 & 39.24 & 8.6277 & 10.57 & 2.4334 & 1.55 & 0.0743 \\
\hline & & $0.064-0.125$ & 1.07 & 0.1177 & 59.23 & 9.2708 & 13.24 & 1.9613 & 0.90 & 0.1059 \\
\hline & & $<0.064$ & 0.87 & 0.0383 & 61.71 & 8.6900 & 16.21 & 1.9937 & 1.14 & 0.1309 \\
\hline & & $0.250-0.500$ * & & ND & $1880^{* * *}$ & ND & 2542.00 & ND & 77.00 & ND \\
\hline \multirow{5}{*}{ 09-МРВ-075 } & \multirow{5}{*}{$2.5 \mathrm{~km}$ down ice } & $0.185-0.250$ & 0.24 & 0.0353 & 22.09 & 7.2143 & 6.56 & 1.6389 & 1.03 & 0.1854 \\
\hline & & $0.125-0.185$ & 0.41 & 0.005 & 27.03 & 6.4038 & 5.62 & 1.6028 & 0.34 & 0.0444 \\
\hline & & $0.064-0.125$ & 0.68 & 0.0399 & 48.04 & 9.3994 & 8.50 & 1.4065 & 1.05 & 0.1107 \\
\hline & & $<0.064$ & 0.27 & 0.0269 & 42.82 & 6.7296 & 8.95 & 1.208 & 1.11 & 0.1458 \\
\hline & & $0.250-0.500$ * & & ND & $3160 * * *$ & ND & 971.00 & ND & 64.00 & ND \\
\hline \multirow{5}{*}{ 12-МРB-902 } & \multirow{5}{*}{$8 \mathrm{~km}$ down ice } & $0.185-0.250$ & 0.3 & 0.0065 & 14.40 & 4.1317 & 5.18 & 1.83 & 0.35 & 0.0462 \\
\hline & & $0.125-0.185$ & 0.32 & 0.0094 & 22.55 & 5.3092 & 5.83 & 1.3816 & 0.83 & 0.2069 \\
\hline & & $0.064-0.125$ & 0.32 & 0.0225 & 32.15 & 6.1219 & 7.35 & 1.335 & 0.56 & 0.0831 \\
\hline & & $<0.064$ & 0.3 & 0.0205 & 33.24 & 4.1088 & 7.83 & 0.8659 & 0.85 & 0.1128 \\
\hline & & $0.250-0.500 *$ & & ND & $620 * * *$ & ND & 1634 & ND & 24 & ND \\
\hline
\end{tabular}

${ }^{*}$ Grain Count, data from Hicken et al. [2]; ${ }^{* *}$ Normalized to 1000 grains; ${ }^{* * *}$ Estimated grain count totals (Geological Survey of Canada, unpublished data); ND = not determined. 


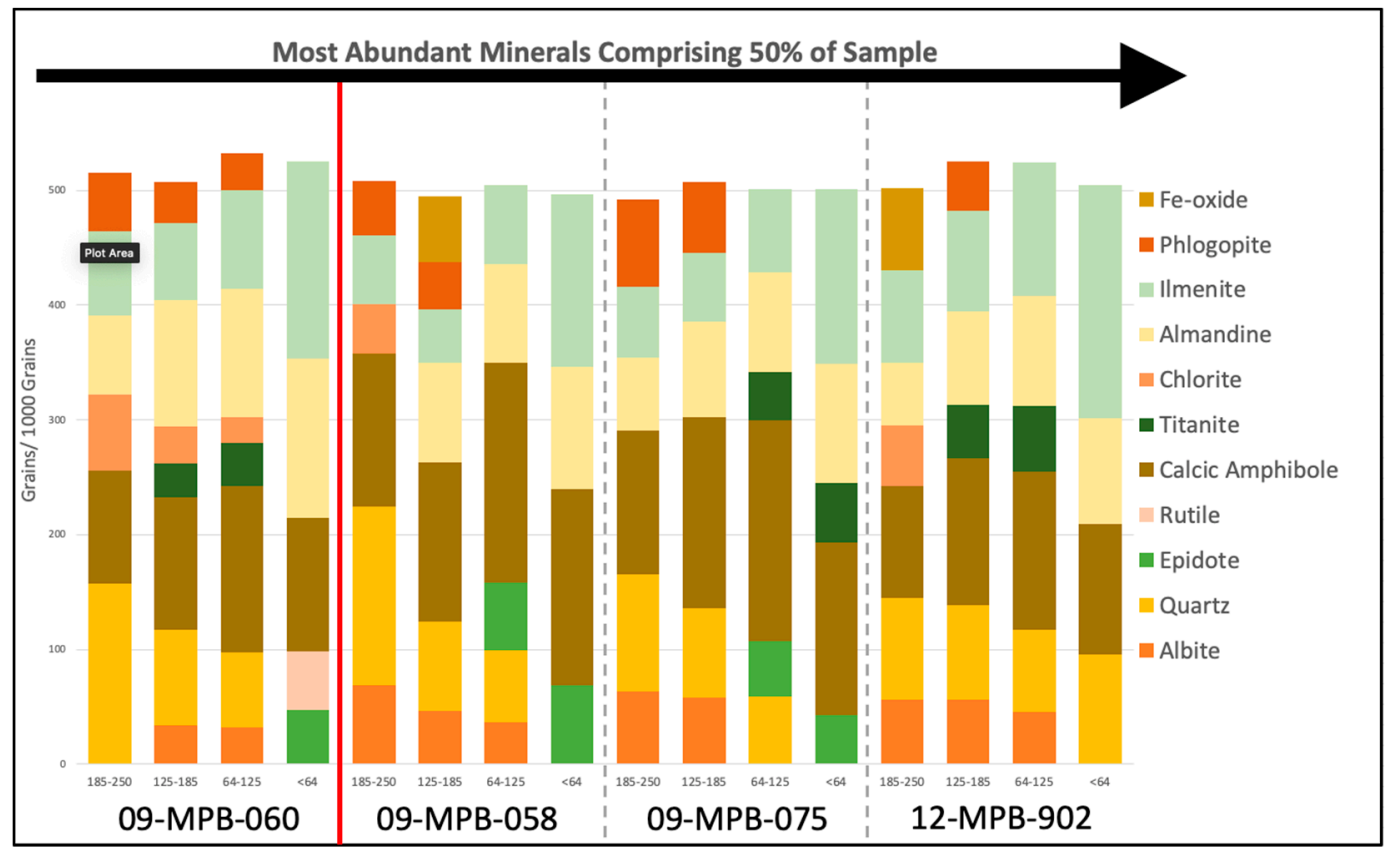

Figure 6. Mineral abundance (normalized to 1000 grains) for the most abundant minerals comprising $50 \%$ of $<250 \mu \mathrm{m}$ till heavy mineral concentrates, for four size fractions of four till samples. Red line denotes the relative position of massive sulfide mineralization, and the black arrow denotes the direction of ice flow.

\subsection{Alteration Minerals and Metamorphic Equivalents}

Gahnite was present in all four till samples, including the sample up ice, with values ranging from 0.03 to 2.30 grains per 1000 grains. Sample 09-MPB-058, immediately down ice of mineralization, contained the most gahnite of the four samples ( 0.90 to 2.30 ). Gahnite was three times more abundant in the coarsest $(185-250 \mu \mathrm{m})$ fraction of this sample as compared to the finer three fractions. Up ice, the $<64 \mu \mathrm{m}$ fraction had the highest abundance of gahnite (0.08), but significantly lower than all down ice samples.

Corundum was identified by Averill [3] as an indicator mineral of metamorphosed massive sulfide deposits and is found intergrown with gahnite grains in till samples down ice of the Izok Lake deposit. Corundum is present in all till samples, with values ranging from 0.14 to 3.59 per 1000 grains. The highest abundances by far ( 0.87 to 3.59$)$ were found in the four fractions of sample 09-MPB-058, immediately down ice of mineralization. Of these four fractions for this sample, corundum is most abundant in the coarsest fraction. The fewest grains of corundum (0.14) were detected in the coarsest fraction of sample 09-MPB-060, $1 \mathrm{~km}$ up ice of the deposit. Corundum grains are intergrown with other minerals, or present as discrete grains.

Corundum grains intergrown with gahnite were identified in all samples down ice of mineralization. These intergrown grains were found in all four size fractions of sample 09-MPB-058, immediately down ice of mineralization, in the 64-125 $\mu \mathrm{m}$ fraction of intermediate distance sample 09-MPB-075 ( $3 \mathrm{~km}$ down ice), and in the 125-185 and $<64 \mu \mathrm{m}$ fractions of distal sample 12-MPB-902 ( $8 \mathrm{~km}$ down ice). Corundum was intergrown with other minerals, including hercynite (Fe-spinel), chlorite, staurolite, Fe-oxide minerals, hornblende and almandine. Corundum, both discrete grains and grains intergrown with gahnite, from proximal down ice sample 09-MPB-058, contained inclusions of the sulfide ore minerals galena and chalcopyrite.

Staurolite abundance ranged from 5.18 to 16.21 grains per 1000 grains. It was present in all four till samples, in all four size fractions. The highest abundance of staurolite (16.21) was detected in sample 
09-MPB-058, just down ice of mineralization. The finest fraction of all four till samples consistently had the highest values of staurolite. In general, content in till decreased as distance down ice increased.

Axinite abundance ranged from 0.03 to 0.33 grains per 1000 grains and was identified in all four fractions of all four till samples. The $64-125 \mu \mathrm{m}$ fraction of sample 09-MPB-075, $3 \mathrm{~km}$ down ice of mineralization, contained the most (0.33) axinite. The least amount of axinite was detected in the 125-185 $\mu \mathrm{m}$ fraction of sample 12-MPB-902, $8 \mathrm{~km}$ down ice. There were no consistent patterns of abundance related to size fractions for the four till samples.

Epidote abundance ranged from 14.4 to 61.71 grains per 1000 grains and was identified in all four size fractions of all four till samples. The $<64 \mu \mathrm{m}$ fraction of till sample 09-MPB-058, $0.5 \mathrm{~km}$ down ice of mineralization, contained the most (61.71) epidote. The least amount was detected in the coarsest $(185-250 \mu \mathrm{m})$ fraction of distal down ice till sample 12-MPB-902 (8 km down ice). The greatest abundance of epidote grains is in the $64-125$ or $<64 \mu \mathrm{m}$ fraction of all till samples.

Fe-oxide minerals were identified in all size fractions of all till samples from Izok Lake, with a notable increase in abundance in the coarsest $(185-250 \mu \mathrm{m})$ fraction in the till samples down ice of mineralization. Fe-oxide mineral abundance ranged from 15.65 to 72.16 grains per 1000 grains and was identified in all four size fractions of all four till samples. The 185-250 $\mu \mathrm{m}$ fraction of till sample 12-MPB-902, $8 \mathrm{~km}$ down ice of mineralization, contained the most (72.16) Fe-oxide. The least amount was detected in the 125-185 $\mu \mathrm{m}$ fraction of till sample 09-MPB-075, located $3 \mathrm{~km}$ down ice of mineralization.

\subsection{Ore Minerals}

Chalcopyrite abundance ranges from 0.02 to 0.40 grains per 1000 grains and was identified in all four till samples. It is most abundant (0.40) in sample 09-MPB-058, just down ice of mineralization, in which it is present in all four size fractions. In this sample, it is most abundant in the coarsest fraction and least abundant in the finest fraction. In fact, chalcopyrite was found in all four fractions (except for the 64-125 $\mu \mathrm{m}$ of one sample) of the three till samples down ice of mineralization. In sample 09-MPB-060, $1 \mathrm{~km}$ up ice of the deposit, chalcopyrite was only identified in very low abundance (0.02) in the finest fraction $(<64 \mu \mathrm{m})$.

Sphalerite is the least abundant of the four ore minerals reported here. It was present only in two till samples, with values ranging from 0.03 to 8.09 grains per 1000 grains. It was found in all four size fractions of sample 09-MPB-058 and in two size fractions (125-185 $\mu \mathrm{m}$ and $<64 \mu \mathrm{m})$ of sample 12-MPB-902, $8 \mathrm{~km}$ down ice. In sample 09-MPB-058, it is most abundant in the coarsest fraction and least abundant in the finest fraction. No sphalerite was detected in the till sample up ice.

The abundance of galena in till samples varies from 0.03 to 0.40 grains per 1000 grains. It is most abundant in sample 09-MPB-058, with the highest abundance in the coarsest (185-250 $\mu \mathrm{m})$ fraction. For each till sample, it is most abundant in the coarsest size fraction. It was also detected in minor amounts in the coarsest fraction of up ice sample 09-MPB-060.

Pyrrhotite abundance ranges from 0.07 to 1.00 grains per 1000 grains. It is most abundant in sample 09-MPB-058, with the highest abundance in the 125-185 $\mu \mathrm{m}$ fraction. It is identified in all size fractions of all till samples, with the highest abundances in the coarsest size fractions observed (185-250 and $125-185 \mu \mathrm{m})$.

Pyrite was found in all four size fractions of all four samples. Values vary between 0.06 and 2.50 grains per 1000 grains. Abundance was highest in sample 09-MPB-058, with pyrite most abundant (2.50) in the coarsest size fraction and least abundant $(0.25)$ in the finest size fraction. Pyrite abundance in till samples 09-MPB-075 and 12-MPB-902, 3 and $8 \mathrm{~km}$ down ice of mineralization respectively, is lower than in till sample 09-MPB-060, $1 \mathrm{~km}$ up ice of mineralization.

Sulfide ore minerals are present in the sample as both discrete, liberated grains and as components in other composite mineral particles. The proportion (area\%) of each ore mineral contained as liberated grains or as part of composite particles is contained in Table 5. 
Table 5. The proportion (area \%) of each ore mineral present as either liberated grains or as a component in a composite particle.

\begin{tabular}{|c|c|c|c|c|c|c|c|c|c|c|c|c|}
\hline \multirow[b]{2}{*}{ Sample } & \multirow[b]{2}{*}{ Location } & \multirow[b]{2}{*}{ Size Fraction (mm) } & \multicolumn{2}{|c|}{ Chalcopyrite } & \multicolumn{2}{|c|}{ Galena } & \multicolumn{2}{|c|}{ Pyrite } & \multicolumn{2}{|c|}{ Pyrrhotite } & \multicolumn{2}{|c|}{ Sphalerite } \\
\hline & & & $\begin{array}{c}\text { Liberated } \\
\text { (area\%) }\end{array}$ & $\begin{array}{l}\text { Composite } \\
\text { (area \%) }\end{array}$ & $\begin{array}{c}\text { Liberated } \\
\text { (area\%) }\end{array}$ & $\begin{array}{c}\text { Composite } \\
\text { (area\%) }\end{array}$ & $\begin{array}{c}\text { Liberated } \\
\text { (area\%) }\end{array}$ & $\begin{array}{c}\text { Composite } \\
\text { (area\%) }\end{array}$ & $\begin{array}{c}\text { Liberated } \\
\text { (area\%) }\end{array}$ & $\begin{array}{l}\text { Composite } \\
\text { (area\%) }\end{array}$ & $\begin{array}{l}\text { Liberated } \\
\text { (area\%) }\end{array}$ & $\begin{array}{c}\text { Composite } \\
\text { (area\%) }\end{array}$ \\
\hline \multirow{4}{*}{ 09-MPB-060 } & \multirow{4}{*}{$1 \mathrm{~km}$ up ice } & $0.185-0.250$ & NA & NA & 0.00 & 100.00 & 0.00 & 100.00 & 0.00 & 100.00 & NA & NA \\
\hline & & $0.125-0.185$ & NA & NA & NA & NA & 0.00 & 100.00 & 0.00 & 100.00 & NA & NA \\
\hline & & $0.064-0.125$ & NA & NA & NA & NA & 0.00 & 100.00 & 0.00 & 100.00 & NA & NA \\
\hline & & $<0.064$ & NA & NA & NA & NA & 0.00 & 100.00 & 0.00 & 100.00 & NA & NA \\
\hline \multirow{4}{*}{ 09-MPB-058 } & \multirow{4}{*}{$\begin{array}{l}0.5 \mathrm{~km} \text { down } \\
\text { ice }\end{array}$} & $0.185-0.250$ & 55.86 & 44.14 & 0.00 & 100.00 & 0.00 & 100.00 & 0.00 & 100.00 & 82.72 & 17.28 \\
\hline & & $0.125-0.185$ & 96.43 & 3.57 & 0.00 & 100.00 & 2.86 & 97.14 & 0.00 & 100.00 & 66.91 & 33.09 \\
\hline & & $0.064-0.125$ & 0.00 & 100.00 & 0.00 & 100.00 & 14.29 & 85.71 & 0.00 & 100.00 & 37.58 & 62.42 \\
\hline & & $<0.064$ & 93.68 & 6.32 & NA & NA & 15.01 & 84.99 & 86.56 & 13.44 & 96.71 & 3.29 \\
\hline \multirow{4}{*}{ 09-MPB-075 } & \multirow{4}{*}{$\begin{array}{c}2.5 \mathrm{~km} \text { down } \\
\text { ice }\end{array}$} & $0.185-0.250$ & 0.00 & 100.00 & 45.05 & 54.95 & 0.00 & 100.00 & 0.00 & 100.00 & NA & NA \\
\hline & & $0.125-0.185$ & 0.00 & 100.00 & NA & NA & 0.00 & 100.00 & 0.00 & 100.00 & NA & NA \\
\hline & & $0.064-0.125$ & NA & NA & 0.00 & 100.00 & 0.00 & 100.00 & 0.00 & 100.00 & NA & NA \\
\hline & & $<0.064$ & 0.00 & 100.00 & NA & NA & 0.00 & 100.00 & 0.00 & 100.00 & NA & NA \\
\hline \multirow{4}{*}{ 12-MPB-902 } & \multirow{4}{*}{$8 \mathrm{~km}$ down ice } & $0.185-0.250$ & 0.00 & 100.00 & 35.09 & 64.91 & 0.00 & 100.00 & 0.00 & 100.00 & NA & NA \\
\hline & & $0.125-0.185$ & 0.00 & 100.00 & NA & NA & 0.00 & 100.00 & 0.00 & 100.00 & 0.00 & 100.00 \\
\hline & & $0.064-0.125$ & 0.00 & 100.00 & 100.00 & 0.00 & 0.00 & 100.00 & 0.00 & 100.00 & NA & NA \\
\hline & & $<0.064$ & 0.00 & 100.00 & NA & NA & NA & NA & 0.00 & 100.00 & 0.00 & 100.00 \\
\hline
\end{tabular}

NA = Not identified in sample. 


\section{Discussion}

\subsection{Consideration for Working with Ultrafine-grained Heavy Minerals}

The size of mineral grains in till reflects the original grain size in bedrock, as well as the effects of glacial erosion, transportation, comminution and deposition on the grains. Dreimanis and Vagners [48] described a bimodal size distribution for specific minerals in till, and the "terminal" grade at which mineral grains become resistant to further comminution. The terminal grade size for most minerals is $<250 \mu \mathrm{m}$, including garnets and other heavy minerals and, therefore, certain indicator minerals may be enriched in a specific size fraction that is $<250 \mu \mathrm{m}$. The transport distance and distribution of this fine, terminal grade material in till is not currently known.

Previous work by Pickett [49] analyzing the fine $(<63 \mu \mathrm{m})$ fraction HMC of till samples identified sample cross-contamination as a significant concern when dealing with fine-grained HMCs. Processing finer-grained sample material increases the difficulty in cleaning sieve surfaces as grains are more easily entrained in void spaces, adhered by electrostatic forces, or lost to aerosolization. Trapped grains may not be readily visible without magnification, making thorough sieve and related sieve equipment cleaning difficult and time consuming. Because low concentrations of indicator minerals (a couple of grains in a $10 \mathrm{~kg}$ sample) can constitute a significant 'anomaly', the potential for false-positive results stemming from sample cross-contamination, or false-negative results stemming from lost indicator grains, requires meticulous sample handling and sieving measures that mitigate mineral grain loss or cross contamination [3]. To address this need, this study utilized single-use nylon-screened sieves following the methods outlined in Lougheed et al. [50]. Single-use sieves eliminate the potential for sample cross-contamination and the need for time-consuming sieve cleaning.

\subsection{Mineral Liberation Analysis (MLA)}

The option to gather information only for grains above a specific brightness threshold is available in MLA. This option was successfully utilized by Hulkki et al. [47], using the grey level of hematite as a lower limit, to increase the detection of $\mathrm{Cu}$-bearing mineral phases in stream sediment HMC samples. These techniques have the added benefit of decreasing the number of EDS analysis necessary during scanning routines, which decreases the overall analysis time for each sample. However, our study analyzed all grains on each polished grain mount.

The parameters that can be generated and queried by MLA (modal mineralogy, mineral associations, grain size, and grain angularity) would be impractical to measure manually for every grain in a sample, and thus automated SEM-based techniques offer the ability to capture both data that are indiscernible to the eye (spectral EDS imagery) and morphological data that would be impossible to measure for every grain with any consistency. These data are collected simultaneously during a single scan, and once collected can be manipulated by a user to examine individual parameters (e.g., prevalence of a single mineral phase) or to examine the relationships between them (e.g., grain size distributions for individual minerals, mineral association data). Because the number of grains available for analysis increases with decreasing size of the mineral grains being examined, the use of automated mineralogy on $<250 \mu \mathrm{m}$ HMC allows for rapid, efficient and cost-effective collection of large amounts of accurate, relatable quantitative data for thousands of grains.

The $<250 \mu \mathrm{m}$ fractions of processed HMC produced in mineral exploration and government surveys are commonly archived immediately after sample processing that recovers the coarse $(>250 \mu \mathrm{m})$ HMC fraction. The $<250 \mu \mathrm{m}$ of HMC may sometimes be pulverized and analyzed geochemically [51,52] but most commonly it is set aside and never examined. Utilizing this previously unused finer size fraction presents an opportunity to gain new insights without the added cost of revisiting the sampling areas or processing additional bulk samples. The false-color mineralogy maps generated by MLA can be used to identify rapidly and accurately indicator minerals that are already known to be in the samples, identify additional indicator minerals that were not previously reported, and identify new indicator minerals that could assist in characterizing the local bedrock geology. These minerals 
can then be examined further using more precise elemental evaluation techniques like laser ablation inductively-coupled plasma mass spectrometry (LA-ICP-MS) or EMPA.

\subsection{Density Gradient and Grain Mounting}

The vertical cross-section slabs 1 and 3 of the primary mounts were prepared in order to evaluate the methods described by Blaskovich [41]. The two vertical slabs for each sub-sample displays a visible trend towards higher particle density (grains per unit area) at the bottom (basal surface) of each mount (Figure 4). They also display a greater proportion of the heaviest (red) particles towards the basal surface of the mount. These slabs demonstrate that a vertical density settling gradient exists through the vertical extent of cured epoxy grain mounts and that the number of grains per unit area is greatest at the base of the vertical slabs. The basal surface of a primary grain mount (Slab 2) consistently contains more heavy mineral grains per unit surface area than throughout the vertical slabs.

The basal surface area of a grain mount that is available for grains to be exposed and imaged is constant $\left(5.07 \times 10^{8} \mu \mathrm{m}^{2}\right)$. However, if variable masses of minerals (e.g., 0.2 vs. $0.3 \mathrm{vs.} 0.5 \mathrm{~g}$ ) are mounted, the preferential settling of the heaviest minerals in the aliquot to be mounted will lead to over representation of the heaviest minerals on the basal surface. This concept is visualized in Figure 5. Therefore, it is important that grain mounts within an individual sampling program be prepared from a consistent mass of sample to ensure accurate comparison between normalized indicator abundances.

Lastra and Petruk [53] used $0.4 \mathrm{~g}$ of material to prepare epoxy grain mounts for automated mineralogy. In our study, $0.3 \mathrm{~g}$ was determined to be a sufficient mass to mount that allowed the most grains to settle on the basal surface of a circular $25 \mathrm{~mm}$ diameter epoxy mount for polishing. This determination was made by experimenting with Almonte till blank heavy mineral concentrate. Grains were added to a ring mount until the base was thinly covered and the mass was recorded. The mass of sample necessary to cover the base of a mount varied depending on the density of the medium being sampled as well as the size fraction being mounted. It is important for each sampling program to determine the appropriate mass of sample to prepare before mounting, and to ensure that this mass is used for all samples.

Automated mineralogical analysis of fine $(<250 \mu \mathrm{m}) \mathrm{HMC}$ permits the counting of very small grains quickly and accurately. The data produced can be used for robust statistical analysis due to the large number of grains sampled and the consistency in the automated EDS collection method. Formerly qualitative assessments of grain morphology or mineral association can now be examined quantitatively using the grain association and angularity statistics calculated within the software. Reducing grain size and subsequently increasing the grains on a mount surface could result in a reduction in bulk sample size if future work finds that indicator mineral concentrations remain representative in a lower bulk sample volume.

It should be noted that the primary mount slabs examined in this study (Slab 2) were all prepared by quartering so there is the potential for biased representation of heavier minerals on the basal surface of the primary mount. The slab 2 surface analyzed only represents $\frac{1}{4}$ of the total basal surface that would routinely be analyzed, thus the total number of grains counted and analyzed are $\frac{1}{4}$ of what would be expected for analysis of the entire basal surface of a $25 \mathrm{~mm}$ epoxy grain mount using the recommended $0.3 \mathrm{~g}$ near-monolayer method described above.

\subsection{MLA Error Estimation}

The error in indicator mineral abundance (area\%) between MLA runs was approximated using the difference between the two values collected from scans of the same section of basal slab 2 on an epoxy grain mount. This is modeled after the work of Voordouw et al. [54], who performed similar repeat scans on thin sections of platinum group mineral (PGM)-bearing mineralized bedrock. Their findings indicate variation of $\pm 7 \mathrm{wt}$. \% for individual base metal sulfide minerals, and $\pm 5 \mathrm{wt}$. \% for individual silicate minerals. When using the MLA software, a section to be scanned in a sample run can be copied and re-applied to the exact same section, ensuring that all frames are analyzed 
in the same location, with the same operating parameters. This overcomes the potential for nugget effects skewing results as described in Hulkki et al. [47]. Their estimation of error had the caveat that their repeat scan could not be performed on precisely the same area, leaving the possibility that grains present along the edges of the scanned area could be missed between consecutive scans. This resulted in differing amounts of $\mathrm{Cu}$ minerals detected between their two runs. Their two runs were performed with differing operating parameters (BSE standards) and, therefore, are not directly comparable to the results of this study.

Error evaluation indicates that MLA reliably identifies and counts most indicator minerals, with negligible variation observed in consecutive runs within and outside of the same scanning routine (Table 2). Axinite-(Mn) $\left.\left(\mathrm{Ca}_{2} \mathrm{Mn}^{2+} \mathrm{Al}_{2}\left(\mathrm{BO}_{3}\right) \mathrm{Si}_{4} \mathrm{O}_{12}(\mathrm{OH})\right)\right)$, an alteration mineral previously identified by Hicken [17] in the coarse $(>250 \mu \mathrm{m})$ fraction of disaggregated mineralized bedrock from Izok Lake, was identified by MLA in the fine $(<250 \mu \mathrm{m})$ fraction of till HMC by this study using MLA. However, the evaluation of error determined that the variability in axinite abundance calculated between runs was consistently higher than that of the other minerals examined $(0.3-0.5 \%)$. The accelerating voltages used by this study are much higher than the optimal overvoltage for light elements like B ( $\sim \mathrm{keV})$ and, therefore, the peak to background ratio will be too low for effective detection of B [55]. The other elements comprising axinite are relatively common, and the high error evaluation by this study suggests that the MLA determination of axinite is being confused with other Ca-, Fe-, or Mn-containing aluminosilicates. The previous visual identification and subsequent EMPA confirmation of axinite in the coarse fraction of till from Izok lake indicates that at least some of the axinite identified by MLA is likely correctly attributed, but the variation in abundance between subsequent scans of the same surface is too high to use as an indicator mineral with this method. The difficulty in consistently and accurately distinguishing axinite from other minerals with similar stoichiometry indicates that axinite evaluation with MLA is not an effective tool for exploration.

The error, as defined by this study, is greater in magnitude when analyzing the coarser $(185-250 \mu \mathrm{m})$ fraction. The difference in errors between the coarse (larger error) and fine size fractions (smaller error) is likely due to the greater number of grains/per unit area analyzed ( 8000 grains in the $<64 \mu \mathrm{m}$ fraction, compared to 4000 grains in the $185-250 \mu \mathrm{m}$ fraction) and, therefore, the difference in statistical sample size. The error is smaller for both size fractions studied after the machine underwent routine gun alignment calibration. These values are acceptable for this study, for two reasons: (1) no minerals of interest were identified in one scan but not in another, and (2) the minerals of interest are present in large enough amounts that these minor fluctuations would not impact the identification of an anomalous abundance. Further, this error evaluation emphasizes the need for regular maintenance on FEG-SEM systems, frequent in-house machine calibration and repeated evaluation of error to ensure consistent results.

\subsection{Modal Mineralogy}

The grain abundance of key indicator minerals at each sample location are displayed in Figure 7 (ore minerals) and Figure 8 (alteration minerals). The $X$-axis represents horizontal distance down ice (NW) of mineralization (at zero). The Y-axis displays the normalized grain counts for each mineral, and the four till sample locations are joined by a curve to visualize the changes in indicator abundance along the length of the glacial dispersal train. Note that the values in the 250-500 $\mu \mathrm{m}$ fraction are normalized to a $10 \mathrm{~kg}$ sample mass and were reported in a previous study [11,18]. Some of these minerals do not have data as they were not counted during that study. 


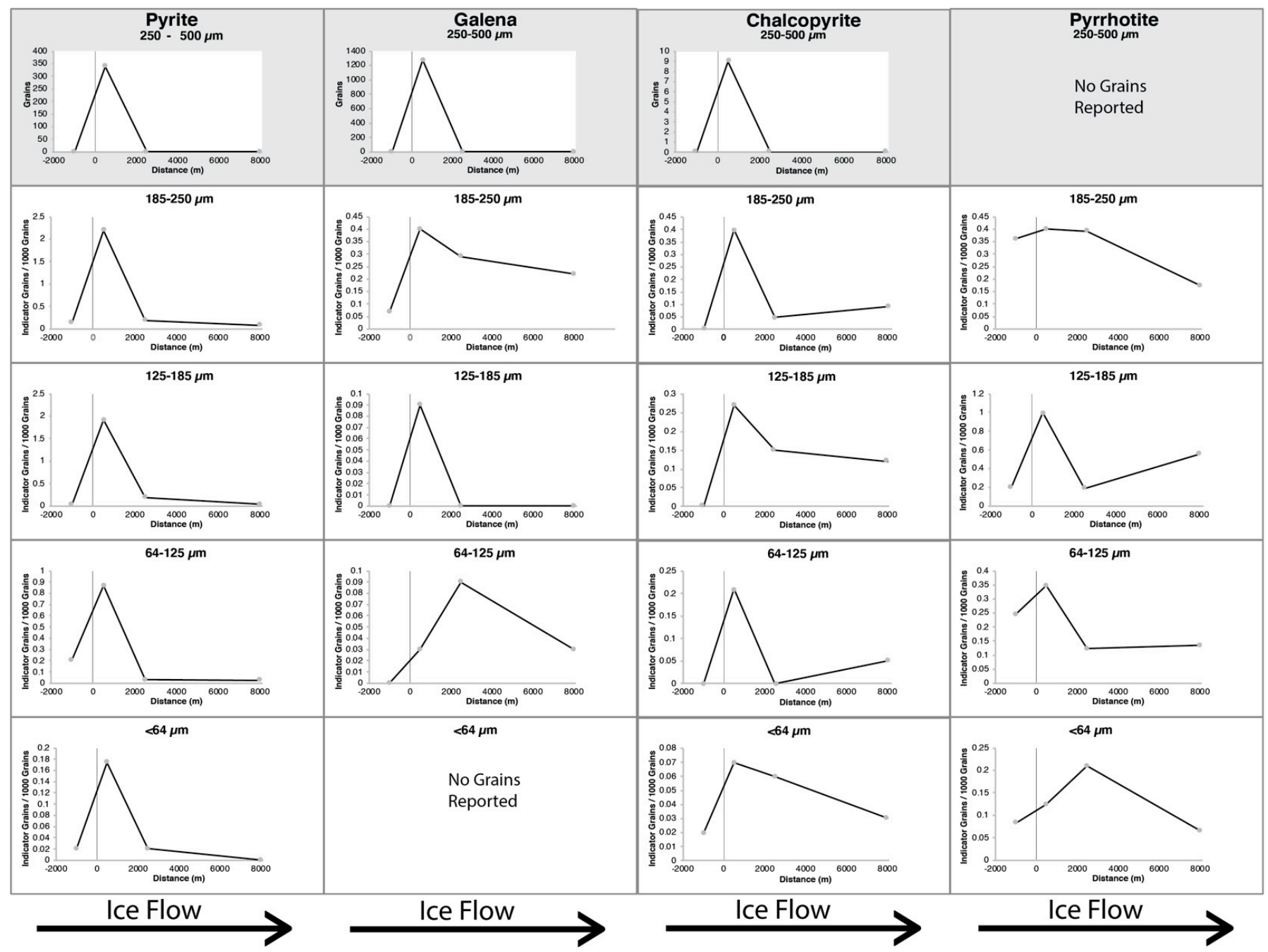

Figure 7. The grain abundance (normalized to 1000 grains) of ore indicator minerals at each sample location, for each size fraction examined. The X-axis of each is a scaled representation in the direction of ice flow (black arrow). The location of mineralization is denoted by the vertical grey line, and the black trend-line depicts the inferred decay in indicator mineral abundance along the dispersal train extending from the deposit. 


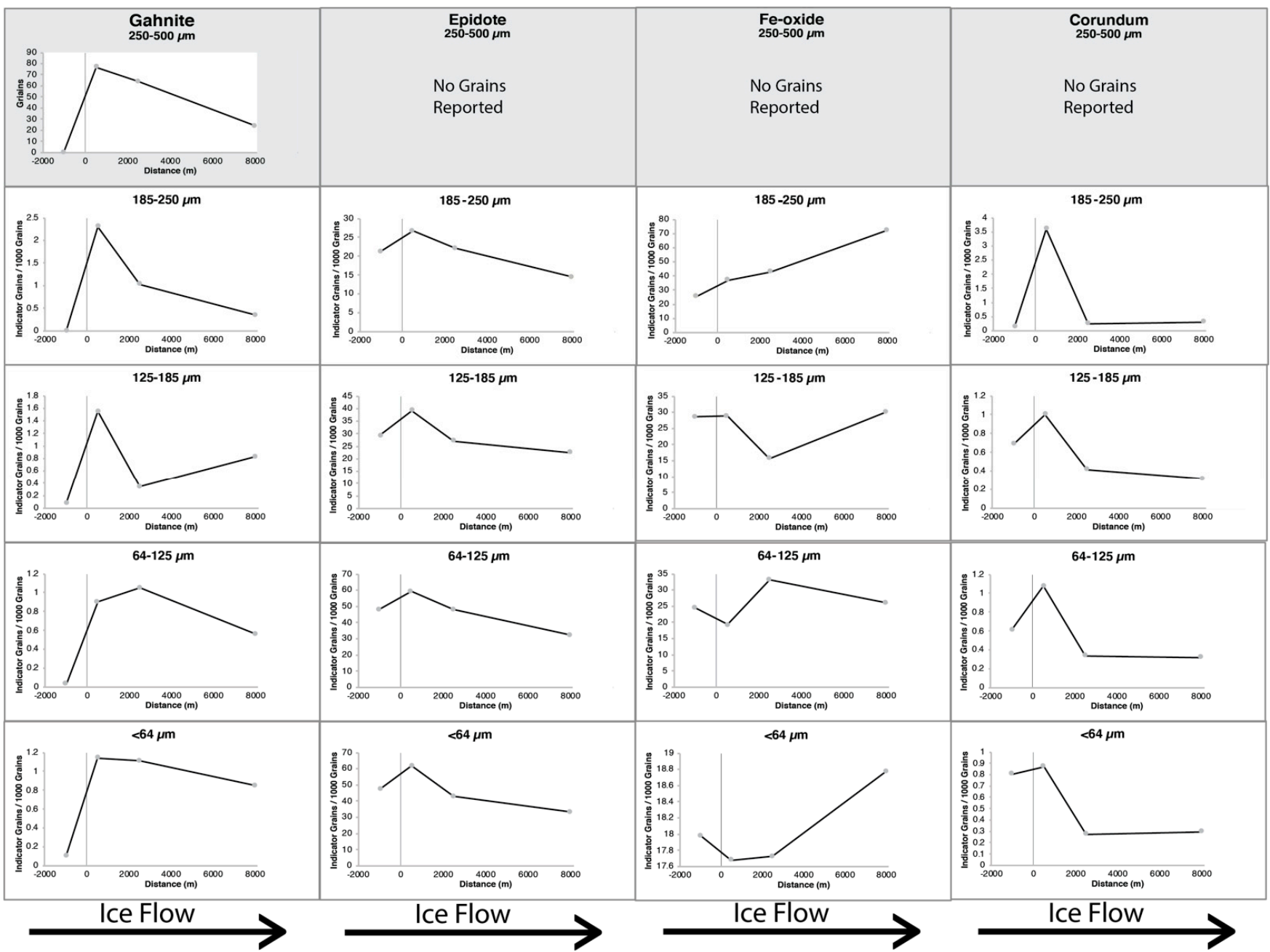

Figure 8. The grain abundance (normalized to 1000 grains) of key alteration indicator minerals at each sample location, for each size fraction examined. The X-axis of each is a scaled representation in the direction of ice flow (black arrow). The location of mineralization is denoted by the vertical grey line, and the black trend-line depicts the inferred decay in indicator mineral abundance along the dispersal train extending from the deposit. 


\subsubsection{Gahnite}

Hicken [17] reported that gahnite in polished thin-section (PTS) ranged between 0.2 and $3.0 \mathrm{~mm}$ in size, and disaggregated bedrock HMC of mineralized bedrock ranged between 0.25 and $1.0 \mathrm{~mm}$ in size. This range reflects the original size of the gahnite presented to the overriding glacier during erosion of the deposit and generation of the till. As these grains were transported down ice they would have been crushed to smaller sizes with increasing transport distance, producing the pattern observed in our samples, i.e decreasing abundance and size of gahnite in till with increasing distance down ice.

The pattern of gahnite abundance in the $<250 \mu \mathrm{m}$ HMC is similar to that observed by McClenaghan et al. [11] and Hicken et al. [18] for the 250 to $500 \mu \mathrm{m} \mathrm{HMC.} \mathrm{Abundance} \mathrm{is} \mathrm{highest}$ in sample 09-MPB-058, immediately down ice of the deposit, and decreases with increasing distance down ice. Of the four size fractions of the most proximal sample, gahnite is most abundant in the coarsest (185-250 $\mu \mathrm{m})$ fraction, whereas in the sample farthest down ice, gahnite is most abundant in the finest size fraction. This is consistent with a model of grain comminution by abrasion and/or crushing during transport down ice, where grains are gradually reduced to a terminal grain size from their original size in bedrock [48]. No gahnite was recovered from the coarse $(>250 \mu \mathrm{m}) \mathrm{HMC}$ fraction of sample 09-MPB-060 up ice of the deposit [18], however, in our study, a few gahnite grains are found in the sample. Because sample 09-MPB-060 is located only $1 \mathrm{~km}$ up ice (east) of massive sulfide mineralization, it is possible that an alteration halo containing fine-grained gahnite extends this far east. Note minor amounts of $0.25-0.5 \mathrm{~mm}$ gahnite grains (few grains/10 kg) were previously reported in regional till samples farther up ice of Izok Lake by McClenaghan et al. [56].

\subsubsection{Corundum}

Morrison [22] identified corundum as a component of the chlorite-biotite-cordierite (CBC) alteration zone, thought to represent the metamorphosed equivalent of the hydrothermally altered feeder-zone for the mineralizing fluids at Izok Lake. Both Hicken [17] and Morrison [22] identify corundum in cordierite-bearing bedrock, whereas Nowak [26] identifies it in the "moderately-altered rhyolite" assemblage defined in his work.

Intergrowths of corundum were previously identified in gahnite grains recovered from till samples at Izok Lake and discrete grains were observed in the polished thin section of one bedrock sample from $2 \mathrm{~km}$ northeast of the deposit by Hicken [18]. Only blue and red corundum were visually scanned for and counted in the 250-500 $\mu \mathrm{m}$ fraction of Izok Lake till samples, but no grains were found in the till samples selected for use in this study. All other colours of corundum were not scanned for in the 250-500 $\mu \mathrm{m}$ fraction. In this study, corundum is identified by MLA in all four size fractions of the $<250 \mu \mathrm{m}$ HMC of all four samples, with a pattern of abundance similar to that of gahnite.

Gahnite-corundum intergrowth is observed in the finer size fractions of the down ice till samples. Corundum has been previously noted in association with gahnite at the Geco VMS deposit, Canada, by Spry [57] and is considered part of a mineral assemblage formed following high-grade metamorphism of chloritic precursor rocks [58]. These chloritic precursor rocks are characteristic of the footwall hydrothermal alteration pipes of VMS deposits [15]. Backscatter SEM images of corundum grains from the $185-250 \mu \mathrm{m}$ fraction reveal that it is intergrown with gahnite, but this relationship is not observed in this coarsest $(185-250 \mu \mathrm{m})$ fraction at any of the other sample sites located down ice (Figure 9). The presence of coarse-grained $(185-250 \mu \mathrm{m})$ intergrown corundum only in the most proximal till sample suggests that corundum and gahnite are liberated from one another by crushing and/or abrasion in the subglacial environment, and that their presence as coarse composite grains could serve as an indicator of close proximity $(<1 \mathrm{~km})$ to a gahnite-rich mineralized source. 


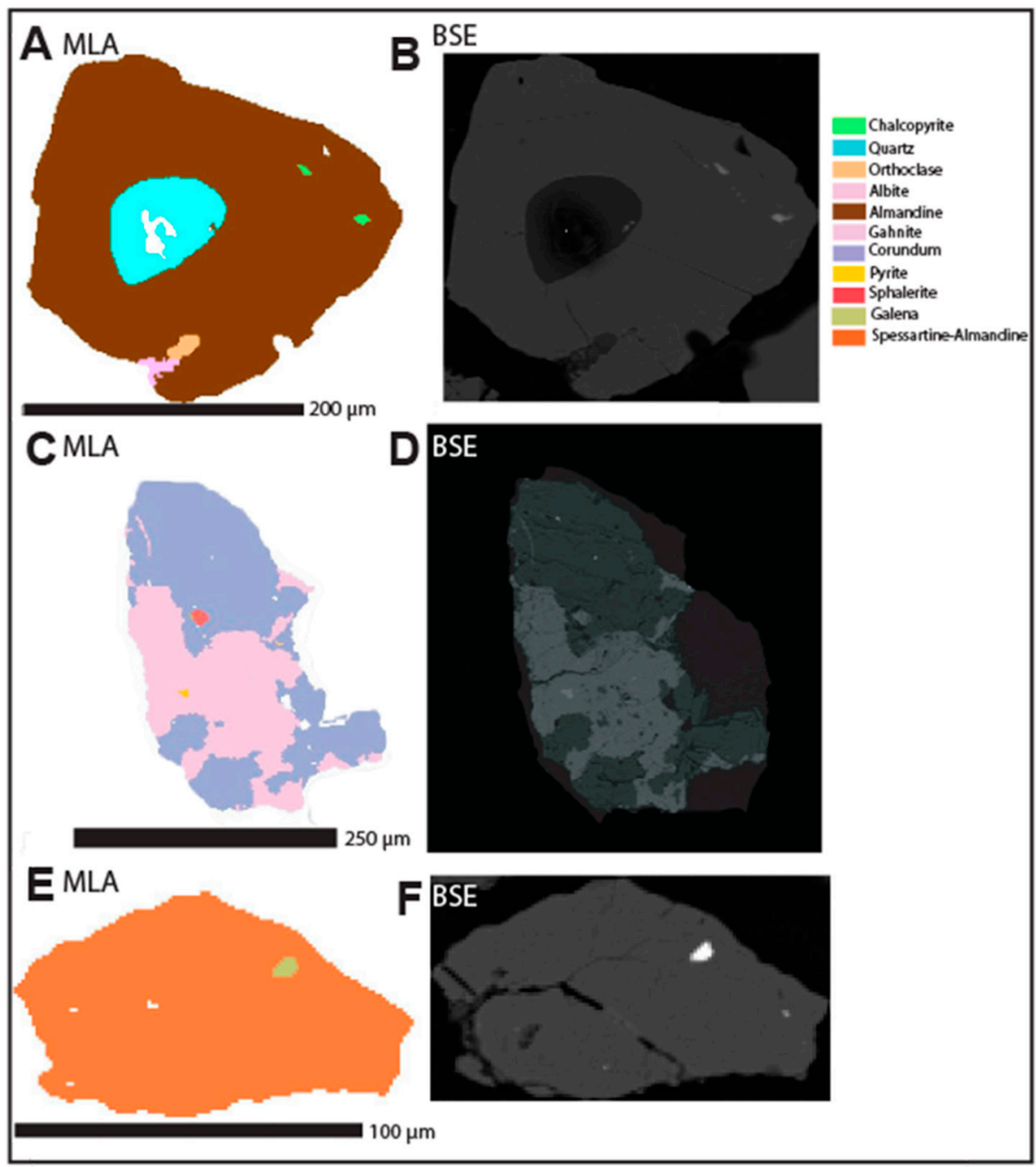

Figure 9. Mineral liberation analysis (MLA) and backscatter emission (BSE) images of mineral grains from till: $(\mathbf{A}, \mathbf{B})$ chalcopyrite inclusions (green) in almandine; (C,D) intergrown gahnite (pink) and corundum (blue); (E,F) galena inclusion (brown) in garnet. Note: scale bars below images vary.

\subsubsection{Epidote}

Epidote was previously reported by Hicken [17], Nowak [26], and Hicken et al. [31] in bedrock PTS and till HMC. Nowak [26] and Hicken [17] identified epidote grains in bedrock. Nowak [26] divided bedrock into domains based on the degree of hydrothermal alteration of the protolith, and epidote was reported in metamorphosed bedrock corresponding to least- and weakly altered protolith, with coarser-grained epidote being found in the weakly altered $(0.2-0.7 \mathrm{~mm})$ assemblages than in the least-altered $(0.1-0.3 \mathrm{~mm})$ assemblages.

Hicken [17] reported epidote grains in four bedrock PTS samples. Two samples (diabase dyke and iron formation) were collected to the west of Iznogoudh Lake ( $>5 \mathrm{~km}$ down ice of the Izok Lake deposit), and two samples (schist and gneiss) were collected from metamorphic rocks $<1.5 \mathrm{~km}$ from the Izok Lake deposit. Epidote in the two proximal bedrock samples was coarser-grained than in the two more distal samples. Green epidote abundance was estimated by ODM for the $0.250-0.500 \mathrm{~mm}$ fraction of till HMC for the four samples examined by this study (Geological Survey of Canada, unpublished data). The counts were only accurate to 10-100 grains, depending on the total number of epidote grains present, but indicate an increase in abundance overlying mineralization, peaking $3 \mathrm{~km}$ down ice at sample site 09-MPB-075 and diminishing at sample site 12-MPB-902, $8 \mathrm{~km}$ down ice (Table 4). 
Epidote identified by this study increases in abundance in the most proximal till sample down ice of mineralization (09-MPB-058), and till samples 09-MPB-060 (1 km up ice) and 09-MPB-075 (3 km down ice) have relatively equal epidote abundance in all size fractions. Till sample 12-MPB-902, $8 \mathrm{~km}$ down ice of mineralization, has the lowest abundance of epidote in all size fractions examined. This suggests that till sample 09-MPB-060 is within the hydrothermal alteration halo of the Izok Lake deposit, which is supported by the extent of hydrothermal alteration described in Morrison [22], who describes a late-stage, widespread zone of calcic alteration containing epidote surrounding the deposit. Epidote has been previously identified as an important indicator in porphyry terranes [8], where epidote abundance and trace element composition can be used in tandem to identify hydrothermal carbonate and propylitic alteration halos and assess ore fertility in porphyry systems. However, the chemical changes associated with carbonate and propylitic alteration lead to bulk-rock compositions similar to those of calc-silicate rocks of sedimentary or metasomatic origin [59] and, therefore, epidote abundance will need to be identified along with other indicator minerals to serve as a vector to VMS mineralization. Future work is needed to investigate the utility of epidote as an indicator mineral for VMS deposits, with careful attention paid to collecting true regional background samples outside the potentially wide zone of propylitic alteration.

\subsubsection{Staurolite}

Staurolite is a common metamorphic mineral in upper amphibolite facies terranes [60]. Its presence in all four till samples is expected as the deposit is in a high metamorphic grade terrane [3]. Staurolite with a significant $\mathrm{Zn}$ content ( $>5 \mathrm{wt}$. \%) was identified as a useful marker when exploring for metamorphosed massive sulfide deposits, specifically as an intermediate mineral to form gahnite through the reaction of $\mathrm{Zn}$-bearing biotite and staurolite during metamorphism [61-64]. However, EMPA analysis of several hundred staurolite grains collected from the $>250 \mu \mathrm{m}$ fraction of till HMC at Izok Lake by Hicken [17] identified very few grains containing $>5 \mathrm{wt}$. \% Zn. Spectra collected from these grains were added to our study's mineral reference library and no significant abundance of Zn-rich staurolite was observed in our samples.

\subsubsection{Fe-Oxide Minerals}

Fe-oxide minerals hematite, goethite, and magnetite have been used as indicator minerals of porphyry $\mathrm{Cu}$ (e.g., Kelley et al. [7]) and VMS mineralization (e.g., Makvandi et al. [65] and McClenaghan et al. [66]). These minerals can be derived from fresh bedrock, sulfide gossans that were glacially eroded and incorporated into glacial sediments, or from postglacial weathering of sulfide grains in till. Automated mineralogical platforms such as MLA cannot distinguish the valence state of individual elements and also has difficulty discerning grain boundaries between minerals of similar atomic (Z) number due to similarities in the grey level in BSE. This means that Fe-oxide minerals (goethite, limonite, hematite, magnetite) are difficult to separate and distinguish using EDS or BSE [45]. The MLA mineral reference library for this project has one entry for Fe-oxide and while it is possible to further differentiate minerals using the data gathered by the MLA based on the amplitude of individual elemental peaks this would have required more time than was permitted during our routine MLA analysis.

The increase in Fe-oxide abundance down ice of the Izok Lake deposit likely represents the incorporation of iron formation, weathered gossanous material from the Izok Lake deposit, the weathering of sulfide grains within till following deposition, or some combination of all three. Mineralized iron formation makes up a portion of the hanging wall immediately east of the deposit [22]. Fe-oxide abundance in the $185-250 \mu \mathrm{m}$ fraction increases in the till progressively farther down ice, with the highest value (72.16 grains per 1000 grains) observed in the $185-250 \mu \mathrm{m}$ fraction of till sample 12-MPB-902, $8 \mathrm{~km}$ down ice of mineralization. It is normal for indicator mineral abundance in till dispersal trains to peak down ice of the weathered source as source material is incorporated relative to the reduction in material transported from up ice [67] and likely accounts for the lower abundance of 
Fe-oxide identified in till sample 09-MPB-058 (0.5 km down ice) compared to till sample 09-MPB-075 ( $3 \mathrm{~km}$ down ice). The further increase in Fe-oxide abundance in distal till sample 12-MPB-902 may reflect the influx of debris from the WIZ showing, $2.5 \mathrm{~km}$ up ice of till sample 12-MPB-902.

\subsubsection{Sulfide Minerals}

Sulfide mineral instability in oxidizing surface environments combined with their low resistance to physical abrasion and crushing result in poor preservation in till [3]. Sulfide grains (chalcopyrite, pyrite, sphalerite) were only detected in the coarse $(250 \mu \mathrm{m})$ fraction of till HMC by Hicken et al. [3] and only in sample 09-MPB-058, immediately down ice of mineralization. Galena was not identified in the $>250 \mu \mathrm{m}$ fraction of any till samples.

This study identifies several sulfide minerals in the $<250 \mu \mathrm{m}$ till HMC, including chalcopyrite, galena, pyrite, sphalerite, and pyrrhotite. The highest abundances of all sulfides are in sample 09-MPB-058, immediately down ice of mineralization, and this establishes values for metal-rich surface till proximal to a VMS deposit in permafrost terrain. In fact, this till sample contains the only significant abundance of sphalerite identified in this study. The relative abundance of sulfide minerals in this proximal metal-rich till sample is sphalerite $>$ pyrite $>$ pyrrhotite $>$ chalcopyrite $>$ galena.

Coarse sphalerite was only visually observed in two of 53 till samples in the GSC study, 09-MPB-058 and 09-MPB-052, both down ice of mineralization between Izok Lake and Iznogoudh Lake. Our study detected sphalerite as discrete grains that occasionally contain inclusions of chalcopyrite or pyrite. The low sphalerite abundance in till in all four size fractions is likely the result of some combination of the following: rapid physical abrasion during glacial transport due to its low hardness (Hardness 3.5-4), chemical weathering of sphalerite postglacially, and perhaps few sphalerite-bearing zones of the deposit being directly exposed to glacial erosion. The low preservation of sphalerite grains in till in all size fractions make it a poor candidate for a till HMC indicator mineral.

Pyrite is a common mineral in mineralized and unmineralized rocks, so its usefulness as an indicator mineral of sulfide mineralization is less obvious. McClenaghan et al. [56] recovered coarse $(>250 \mu \mathrm{m})$ pyrite in five till samples: 09-MPB-058, $-016,-081,-052$ and -030 , with the highest abundance in samples 09-MPB-081 (56 grains) just up ice of mineralization, and 09-MPB-058 (338 grains) and -016 (82 grains) $500 \mathrm{~m}$ down ice of mineralization. Lower abundances were recovered from samples 09-MPB-052 (24 grains) and -030 (13 grains) $1 \mathrm{~km}$ and $5 \mathrm{~km}$ down ice of mineralization, respectively. No pyrite grains were recovered from till sample 09-MPB-060 up ice of the deposit.

Pyrite abundance in $<250$ till HMC at Izok Lake is different. Abundance is highest immediately down ice of mineralization but reaches background levels (0.2-0.4 grains per 1000 total grains) in most size fractions at sample site 09-MPB-075, $3 \mathrm{~km}$ down ice of mineralization. In the $<64 \mu \mathrm{m}$ fraction, pyrite values remain elevated above background (0.06 grains per 1000 total grains) up to sample site 12-MPB-902, $10 \mathrm{~km}$ down ice of mineralization. This pattern suggests that till sample site 09-MPB-060 (1 km up ice) may not represent the background for most size fractions, or that pyrite in the coarse fraction is rapidly comminuted to the finer fraction by abrasion and crushing during glacial transport. The high concentrations of pyrite overlying and just down ice of base metal mineralization indicates that it can be a useful indicator in combination with other sulfide minerals, and the dispersal distance may be greater when examining the finest $(<64 \mu \mathrm{m})$ fraction. Pyrite occurs in both discrete grains and as inclusions in other grains (Table 5), and some grains containing pyrite inclusions also contain inclusions of chalcopyrite (Figure 9) and pyrrhotite. Rapidly identifying these fine pyrite inclusions can generate targets for more precise analytical tools (EMPA, LA-ICP-MS) as pyrite geochemistry has been used in exploration for lode Au [68] and Sedimentary Exhalative (SEDEX) base metal [69] deposits.

Chalcopyrite has been noted as more resistant to weathering in oxidized till by Averill [3]. Chalcopyrite was reported in disaggregated bedrock HMC and bedrock PTS by Hicken [17] and Hicken et al. [31]. Chalcopyrite in bedrock HMC ranged in size between 0.015 and $1.0 \mathrm{~mm}$, and in bedrock PTS ranged in size between 0.1 and $5 \mathrm{~mm}$. McClenaghan et al. [56] reported 
chalcopyrite in the $250-500 \mu \mathrm{m}$ fraction of till HMC from Izok Lake, primarily in samples located within $1 \mathrm{~km}$ down ice of the deposit.

In our study, chalcopyrite is present in the $<250 \mu \mathrm{m}$ fraction of the three till samples overlying and down ice of mineralization, along with a small number of grains in the finest fraction of sample 09-MPB-060, directly up ice of the deposit. The presence of chalcopyrite in the fine fraction of till is significant because it represents an increase in the dispersal distance down ice from $1 \mathrm{~km}$ for the $>250 \mu \mathrm{m}$ HMC fraction to at least $8 \mathrm{~km}$ for the $<250 \mu \mathrm{m}$ HMC fraction. Chalcopyrite is predominantly present as inclusions in other, more robust grains (Figure 9) such as epidote, hornblende, garnet, and Fe-oxide.

Chalcopyrite and pyrite are commonly present in small amounts in mineralized and barren metamorphosed mafic rocks, and thus the presence of chalcopyrite or pyrite inclusions in other minerals alone, although most likely related to mineralization at this specific site, can be an unreliable indication of mineralization in a regional exploration context [47]. The preservation of chalcopyrite and pyrite as inclusions in more robust grains, combined with the common occurrence of both minerals in mineralized and unmineralized bedrock, means that establishing accurate background values for both minerals is important when using automated mineralogical methods. The presence of whole grains of chalcopyrite and pyrite in till HMC (Table 5) remains a valuable indicator of proximity to mineralization given the relatively rapid physical and chemical weathering of sulfide grains following glacial transport and deposition. The identification of decreasing abundance in dispersal trains at a more detailed survey level can still be useful when vectoring to targets, and the ability of automated mineralogical systems to detect small inclusions of sulfide minerals on polished surfaces preserved as inclusions in other minerals makes them a better tool for this task than optical identification methods.

Hicken [17] reported the presence of galena in the 250-500 $\mu \mathrm{m}$ HMC fraction of only one till sample, collected $1 \mathrm{~km}$ down ice of mineralization. The abundance of galena (area percentage) in the samples down ice of the deposit is minor, but the grain abundance is anomalously elevated in the coarsest (180-250 $\mu \mathrm{m}$ ) of the four fractions of each sample (Tables 3 and 4), highlighting the utility of reporting both area percentage and grain abundance data for indicator minerals. Area percentage values alone would not qualify this sample as anomalous but combined with grain abundance information indicates that galena is present as multiple very small grains.

The anomalous grain counts are due to the presence of small $(10-15 \mu \mathrm{m})$ galena inclusions in other minerals (garnet, hornblende, chlorite) with most inclusions in the coarsest fraction, extending up to $8 \mathrm{~km}$ down ice of mineralization. Galena is not identified in the finest $(<64 \mu \mathrm{m}) \mathrm{HMC}$ fraction of the four till samples. This distribution represents a significant increase of galena dispersal distance from a single sample $1 \mathrm{~km}$ down ice to $8 \mathrm{~km}$ down ice. This suggests that very fine galena inclusions in coarser grains, previously not identifiable with optical methods, are an important indicator of this style of mineralization, significantly extending the dispersal train of an ore mineral that is poorly preserved as whole grains in till.

No pyrrhotite was recovered from the coarse non-ferromagnetic HMC of till samples in the previous GSC study because pyrrhotite would have been removed during ferromagnetic separation. Pyrrhotite detected in the $<250 \mu \mathrm{m}$ fraction of non-ferromagnetic till HMC by this study is present as inclusions in composite grains where the pyrrhotite content is so minor that the magnetic forces of attraction could not overcome the mass of the grain. The abundance of pyrrhotite in the $<250 \mu \mathrm{m} H \mathrm{HC}$ fraction of sample 09-MPB-060, $1 \mathrm{~km}$ up ice of mineralization, is comparable to the amount identified in till sample 09-MPB-075, located $3 \mathrm{~km}$ down ice (west) of mineralization. This distribution suggests that either (1) the abundance of pyrrhotite in till has diminished to regional background levels within $3 \mathrm{~km}$ of down ice, or (2) that up ice sample 09-MPB-060 (1 km up ice) does not represent the regional background for pyrrhotite.

\subsubsection{Silver-Bearing Minerals}

The Izok Lake deposit is a significant Ag resource [70], and the previous study of local tills around the deposit by [17,18] and McClenaghan et al. [11] identified Ag as a pathfinder element 
in the $<63 \mu \mathrm{m}$ matrix fraction of till [71]. Chalcopyrite in the Izok Lake deposit is known to be Ag-rich, containing up to 200-550 ppm Ag [70]. Because the lower detection limits for most elements using EDS are $\sim 1000 \mathrm{ppm}$, the concentrations of Ag in chalcopyrite grains identified in our study will only be detectable in concentrations $>1000 \mathrm{ppm}$. None were found to contain such high amounts of $\mathrm{Ag}$ which explains the lack of Ag-bearing minerals identified in this study.

\subsubsection{Pathfinder Minerals}

Green epidote and Fe-oxides are common minerals in many rock types and deposits and, therefore, are typically found in much higher abundance in till than traditional indicator minerals (S.A. Averill, Pers. Comm), thus their abundance are not routinely determined in the $>250 \mu \mathrm{m}$ fraction. MLA is ideally suited to quantifying their abundances as XBSE scans count every mineral present on a sample surface. Once regional background abundance values are established, anomalous elevated abundances, similar to those observed for epidote and Fe-oxide in our study, can be recognized. Epiote and Fe-oxide minerals are common and the presence in till would not be of note on their own; however, coincident increases in their abundance over the same spatial area highlight a potential area of interest for follow-up mineral exploration, especially when combined with the presence of sulfide minerals. The relationship between these minerals and traditional ore indicator minerals is similar to that of "pathfinder elements" and "indicator elements" in regional geochemical exploration and underscores the potential for automated mineralogy to be a powerful tool in an exploration context.

\section{Conclusions}

This study is the first examination of $<250 \mu \mathrm{m}$ heavy mineral fraction of till HMC from around a high grade (upper amphibolite-sillimanite) metamorphosed VMS deposit in permafrost terrain using automated mineralogical techniques. It also presents a comprehensive methodology for handling and preparing the sample material to mitigate both grain loss and sample cross contamination. Data reported here can be compared to future automated mineralogy studies of the fine fraction of till to help to establish background and "anomalous" abundances that could be expected in till close to such a deposit. Major findings of our study include:

1) The basal surface of epoxy grain mounts contains a greater number of heavy mineral grains than cross-sectional surfaces and represents the optimal surface for MLA studies. A mass of $0.3 \mathrm{~g}$ of heavy minerals will cover the basal surface of a $25 \mathrm{~mm}$ mount, although the mass can be adjusted to suit the density of the minerals to be mounted. Once the appropriate sample mass has been established, all mounts should be prepared using that mass to ensure relatable results between the samples.

2) Error between analytical runs of identical sections can be minimized with regular calibration of FEG-SEM systems. Calibration takes $\sim 20 \mathrm{~min}$ to complete and should be performed prior to each batch of samples being run. The average error (as measured by this study) is not significant $(< \pm 1 \% \mathrm{shift} / \mathrm{mineral})$. Increasing the number of grains presented for analysis improves statistical accuracy by decreasing the influence of outliers and nugget effects on indicator mineral counts.

3) Reporting indicator mineral abundance as both a normalized grain count and area percentage allows for inference about mineral occurrence that would not be possible using only one metric. Normalization of grain count values to 1000 grains ensures that abundance data can be compared between samples and projects and are intuitive to use. Interpreted along with area percentage values, these combined datasets can suggest whether a mineral is present as smaller numbers of larger grains or many small grains.

4) Common ore (chalcopyrite, galena, pyrite, sphalerite, pyrrhotite) and alteration (gahnite, axinite, corundum, epidote, Fe-oxide, staurolite) minerals of metamorphosed VMS deposits were detectable in the fine $(<250 \mu \mathrm{m}$ fraction) of till HMC from the Izok Lake area. Elevated 
abundances of chalcopyrite and galena were detected up to $8 \mathrm{~km}$ down ice, a significant increase over the $1.3 \mathrm{~km}$ sulfide dispersal distance reported by McClenaghan et al. [11].

5) Epidote and Fe-oxide form a dispersal train down ice of the Izok Lake deposit. Epidote is a characteristic mineral in carbonate and propylitic alteration halos surrounding hydrothermal deposits, as well as in calc-silicate rocks of sedimentary or metasomatic origin and, therefore, epidote abundance must rely on the presence of other indicator minerals to be of use to exploration efforts. Care must be taken to ensure that accurate regional background abundance is established outside of wide-spread carbonate and propylitic alteration halos. Future work should investigate the use of trace-element compositional analysis of epidote grains to assess terrane fertility, after the work of Plouffe et al. [8] on porphyry systems. Fe-oxide minerals can indicate the incorporation of gossanous material into till [72] or the weathering of sulfide grains during transport or following deposition. Not all gossans will be found with associated mineralized sulfide bodies (i.e., the WIZ showing) but the fact that they indicate that a mineralized system existed at one point in time makes them an important exploration target.

6) Automated mineralogy can identify indicator minerals that are difficult or impossible to distinguish using traditional optical methods, or that are present only as small inclusions (galena) in other, more robust grains. Another advantage of automated mineralogy is that mineral associations within grains can be quickly identified and quantified (corundum/gahnite). Conversely, visual color of grains when using optical methods can be used to rapidly distinguish minor-element enrichment in some minerals (e.g., red for Mn-epidote, red for Cr-rich rutile). MLA can only recognize these grains if corresponding X-ray spectra have already been identified and added to the mineral reference library.

7) Large numbers of galena and chalcopyrite were identified in the coarsest two size fractions (125-185 $\mu \mathrm{m}$ and $185-250 \mu \mathrm{m})$ of till, at greater distances $(\geq 8 \mathrm{~km})$ down ice than previously identified in the $>250 \mu \mathrm{m}$ size fraction of the same till samples. Corundum, found in composite grains with gahnite, was found in the coarsest fraction examined in the sample most proximal to the deposit. All other alteration minerals (staurolite, gahnite, epidote, Fe-oxides) were found in these coarsest two fractions. Using the 125-250 $\mu \mathrm{m}$ (fine sand) size fraction will reduce the scanning time necessary for each sample, while still presenting 50,000-100,000 grains for analysis on a polished grain mount surface. We believe that at this location the fine sand $(125-250 \mu \mathrm{m})$ fraction of till HMC is the most effective fraction to use with automated mineralogy for detection of indicator mineral anomalies.

Author Contributions: Conceptualization, H.D.L. and M.B.M. and D.L.-M.; methodology, H.D.L. and D.L.-M.; software, H.D.L; validation, H.D.L. and M.B.M. and D.L.-M. and M.L.; formal analysis, H.D.L; investigation, H.D.L.; resources, D.L.-M. and M.B.M.; data curation, H.D.L.; writing—original draft preparation, H.D.L.; writing-review and editing, M.B.M. and D.L.-M. and M.L.; visualization, H.D.L.; supervision, M.B.M. and D.L.-M. and M.L.; project administration, H.D.L.; funding acquisition, M.B.M. and D.L.-M. All authors have read and agreed to the published version of the manuscript.

Funding: This research was funded by Natural Resource Canada's Targeted Geoscience Initiative Program (TGI-5) through a Research Affiliate Program (RAP) bursary to the senior author as part of his Ph.D. research.

Acknowledgments: The authors would like to thank the team at Overburden Drilling Management Limited their assistance with all questions relating to sample processing and indicator mineral methods, Agatha Dobosz at Queen's University for invaluable help with instrument operation, and Jan Peter at the Geological Survey of Canada for sharing his knowledge of the mineralogy of the deposit.

Conflicts of Interest: The authors declare no conflict of interest

\section{References}

1. McClenaghan, M.B.; Kjarsgaard, B.A. Indicator Mineral and Surficial Geochemical Exploration Methods for Kimberlite in Glaciated Terrain: Examples from Canada. In Mineral Deposits of Canada: A Synthesis 
of Major Deposit-Types, District Metallogeny, the Evolution of Geological Provinces, and Exploration Methods; Goodfellow, W., Ed.; Geological Association of Canada: St. John's, NL, Canada, 2007; pp. 983-1006.

2. Averill, S.; Zimmerman, J. The Riddle Resolved-The Discovery of the Partridge Gold Zone Using Sonic Drilling in Glacial Overburden at Waddy Lake, Saskatchewan. In CIM Bulletin; Canadian Institute of Mining, Metallurgy, and Petroleum: Montreal, QC, Canada, 1984; Volume 77, p. 88.

3. Averill, S.A. The application of heavy indicator mineralogy in mineral exploration with emphasis on base metal indicators in glaciated metamorphic and plutonic terrains. Geol. Soc. Spec. Publ. 2001, 185, 69-81. [CrossRef]

4. Averill, S.A. Discovery and Delineation of the Rainy River Gold Deposit Using Glacially Dispersed Gold Grains Sampled by Deep Overburden Drilling: A 20 Year Odyssey. In New Frontiers for Exploration in Glaciated Terrain; Paulen, R., McClenaghan, M.B., Eds.; Open File 7374; Geological Survey of Canada: Ottawa, ON, Canada, 2013; pp. 37-46.

5. McClenaghan, M.B.; Cabri, L.J. Review of gold and platinum group element (PGE) indicator minerals methods for surficial sediment sampling. Geochem. Explor. Environ. Anal. 2011, 11, 251-263. [CrossRef]

6. Hashmi, S.; Ward, B.; Plouffe, A.; Leybourne, M.; Ferbey, T. Geochemical and mineralogical dispersal in till from the Mount Polley $\mathrm{Cu}-\mathrm{Au}$ porphyry deposit, central British Columbia, Canada. Geochem. Explor. Environ. Anal. 2015, 15, 234-249. [CrossRef]

7. Kelley, K.D.; Eppinger, R.G.; Lang, J.; Smith, S.M.; Fey, D.L. Porphyry Cu indicator minerals in till as an exploration tool: Example from the giant Pebble porphyry $\mathrm{Cu}-\mathrm{Au}-\mathrm{Mo}$ deposit, Alaska, USA. Geochem. Explor. Environ. Anal. 2011, 11, 321-334. [CrossRef]

8. Plouffe, A.; Ferbey, T.; Hashmi, S.; Ward, B. Till geochemistry and mineralogy: Vectoring towards Cu porphyry deposits in British Columbia, Canada. Geochem. Explor. Environ. Anal. 2016, 16, 213-232. [CrossRef]

9. Averill, S.A. Viable indicator minerals in surficial sediments for two major base metal deposit types: $\mathrm{Ni}-\mathrm{Cu}-\mathrm{PGE}$ and porphyry Cu. Geochem. Explor. Environ. Anal. 2011, 11, 279-291. [CrossRef]

10. McClenaghan, M.B.; Paulen, R. Application of Till Mineralogy and Geochemistry to Mineral Exploration. In Past Glacial Environments; Menzies, J., Van der Meer, J., Eds.; Elsevier: Amsterdam, The Netherlands, 2018; pp. 689-751.

11. McClenaghan, M.; Paulen, R.; Layton-Matthews, D.; Hicken, A.; Averill, S. Glacial dispersal of gahnite from the Izok Lake $\mathrm{Zn}-\mathrm{Cu}-\mathrm{Pb}-\mathrm{Ag}$ VMS deposit, northern Canada. Geochem. Explor. Environ. Anal. 2015, 15, 333-349. [CrossRef]

12. Plouffe, A.; McClenaghan, M.; Paulen, R.; McMartin, I.; Campbell, J.; Spirito, W. Processing of glacial sediments for the recovery of indicator minerals: Protocols used at the Geological Survey of Canada. Geochem. Explor. Environ. Anal. 2013, 13, 303-316. [CrossRef]

13. McClenaghan, M. Overview of common processing methods for recovery of indicator minerals from sediment and bedrock in mineral exploration. Geochem. Explor. Environ. Anal. 2011, 11, 265-278. [CrossRef]

14. Lehtonen, M.; Lahaye, Y.; O’Brien, H.; Lukkari, S.; Marmo, J.; Sarala, P. Novel Technologies for Indicator Mineral-Based Exploration; Geological Survey of Finland: Espoo, Finland, 2015; pp. 23-62.

15. Galley, A.G.; Hannington, M.D.; Jonasson, I. Volcanogenic Massive Sulphide Deposits. In Mineral Deposits of Canada: A Synthesis of Major Deposit-Types, District Metallogeny, the Evolution of Geological Provinces, and Exploration Methods; Goodfellow, W., Ed.; Geological Association of Canada: St. John's, NL, Canada, 2007; Volume 5, pp. 141-161.

16. McClenaghan, M.B.; Peter, J.M. Till geochemical signatures of volcanogenic massive sulphide deposits: An overview of Canadian examples. Geochem. Explor. Environ. Anal. 2016, 16, 27-47. [CrossRef]

17. Hicken, A. Glacial Dispersal of Indicator Minerals from the Izok Lake $\mathrm{Zn}-\mathrm{Cu}-\mathrm{Pb}-\mathrm{Ag}$ VMS Deposit, Nunavut, Canada. Master's Thesis, Queen's University, Kingston, ON, Canada, 2012.

18. Hicken, A.; McClenaghan, M.; Layton-Matthews, D.; Paulen, R.; Averill, S.; Crabtree, D. Indicator Mineral Signatures of the Izok Lake Zn-Cu-Pb-Ag Volcanogenic Massive Sulphide Deposit, Nunavut: Part 2 Till; Open File 7343; Geological Survey of Canada: Ottawa, ON, Canada, 2013.

19. Bleeker, W.; Hall, B. The Slave Craton: Geological and Metallogenic Evolution. In Mineral Deposits of Canada: A Synthesis of Major Deposit-Types, District Metallogeny, the Evolution of Geological Provinces, and Exploration Methods; Goodfellow, W., Ed.; Geological Association of Canada: St. John's, NL, Canada, 2007; Volume 5, pp. 849-879.

20. Bleeker, W.; Ketchum, J.W.; Jackson, V.A.; Villeneuve, M.E. The Central Slave Basement Complex, Part I: Its structural topology and autochthonous cover. Can. J. Earth Sci. 1999, 36, 1083-1109. [CrossRef]

21. Buchan, K.L.; Ernst, R. Diabase Dyke Swarms and Related Units in Canada and Adjacent Regions; Geological Survey of Canada: Ottawa, ON, Canada, 2004. 
22. Morrison, I. Geology of the Izok massive sulfide deposit, Nunavut Territory, Canada. Explor. Min. Geol. 2004, 13, 25-36. [CrossRef]

23. Morrison, I.; Balint, F. Geology of the Izok Lake Massive Sulphide Deposits, Northwest Territories, Canada. In Proceedings of the World Zinc'93 Symposium, Hobart, Australia, 10-13 October 1993; pp. 161-170.

24. Bostock, H.H. Geology of the Itchen Lake Area, District of Mackenzie; Geological Survey of Canada: Ottawa, ON, Canada, 1980.

25. Thomas, A. Volcanic Stratigraphy of the Izok Lake Greenstone Belt, District of Mackenzie, NWT. Ph.D. Thesis, University of Western Ontario, London, ON, Canada, 1978.

26. Nowak, R. The Nature and Significance of High-grade Metamorphism and Intense Deformation in the Izok VHMS Alteration Halo and Deposit. Master's Thesis, Colorado School of Mines, Golden, CO, USA, 2012.

27. Money, P.; Heslop, J. Geology of the Izok Lake massive sulphide deposit. Can. Min. J. 1976, 97, $24-27$.

28. MMG Limited Izok Corridor. Available online: https://www.mmg.com/our-business/development-projects/ (accessed on 29 March 2020).

29. Costello, K.; Senkow, M.; Bigio, A.; Budkewitsch, P.; Ham, L.; Mate, D. Nunavut Mineral Exploration, Mining and Geoscience Overview 2011; Aboriginal Affairs and Northern Development Canada: Ottawa, ON, Canada, 2012.

30. Stubley, M.; Irwin, D. Bedrock Geology of the Slave Craton, Northwest Territories and Nunavut; NWT Open File 2019-01; Northwest Territories Geological Survey: Yellowknife, NT, Canada, 2019.

31. Hicken, A.; McClenaghan, M.; Layton-Matthews, D.; Paulen, R.; Averill, S.; Crabtree, D. Indicator Mineral Signatures of the Izok Lake $\mathrm{Zn}-\mathrm{Cu}-\mathrm{Pb}-\mathrm{Ag}$ Volcanogenic Massive Sulphide Deposit, Nunavut: Part 1 Bedrock Samples; Open File 7173; Geological Survey of Canada: Ottawa, ON, Canada, 2013.

32. Dredge, L.; Kerr, D.; Ward, B. Surficial Geology, Point Lake, District of Mackenzie, Northwest Territories; Geological Survey of Canada: Ottawa, ON, Canada, 1996.

33. Stea, R.; Johnson, M.; Hanchar, D.; Paulen, R.; McMartin, I. The Geometry of Kimberlite Indicator Mineral Dispersal Fans in Nunavut, Canada. In Application of Till and Stream Sediment Heavy Mineral and Geochemical Methods to Mineral Exploration in Western and Northern Canada, Short Course Notes; McMartin, I., Paulen, R., Eds.; Geological Association of Canada: St. John's, NL, Canada, 2009; Volume 18, pp. 1-13.

34. Dyke, A.; Prest, V. Late Wisconsinan and Holocene history of the Laurentide ice sheet. Géographie Physique et Quaternaire 1987, 41, 237-263. [CrossRef]

35. Dyke, A.S. An Outline of North American Deglaciation with Emphasis on Central and Northern Canada. In Developments in Quaternary Sciences; Elsevier: Amsterdam, The Netherlands, 2004; Volume 2, pp. 373-424.

36. Paulen, R.C.; McClenaghan, M.B.; Hicken, A.K. Regional and local ice-flow history in the vicinity of the Izok Lake Zn-Cu-Pb-Ag deposit, Nunavut. Can. J. Earth Sci. 2013, 50, 1209-1222. [CrossRef]

37. Shilts, W.W. Nature and genesis of mudboils, central Keewatin, Canada. Can. J. Earth Sci. 1978, 15, $1053-1068$. [CrossRef]

38. Dredge, L.; Ward, B.C.; Kerr, D.E. Trace Element Geochemistry and Gold Grain Results from Till Samples, Point Lake, Northwest Territories (86H); Open File 3317; Geological Survey of Canada: Ottawa, ON, Canada, 1996.

39. Oviatt, N.M. Till geochemistry of the West Iznogoudh Zn Showing, Point Lake Map Sheet (86H), Nunavut. Bachelor's Thesis, University of Calgary, Calgary, AB, Canada, 2010.

40. Lougheed, H.D.; McClenaghan, M.B.; Layton-Matthews, D.; Leybourne, M. Evaluation of Single-Use Nylon Screened Sieves for Use with Fine-Grained Sediment Samples; Open File 8613; Geological Survey of Canada: Ottawa, ON, Canada, 2019; p. 14.

41. Blaskovich, R.J. Characterizing Waste Rock Using Automated Quantitative Electron Microscopy. Master's Thesis, University of British Columbia, Vancouver, BC, Canada, 2013.

42. Kjellsen, K.; Monsøy, A.; Isachsen, K.; Detwiler, R. Preparation of flat-polished specimens for SEM-backscattered electron imaging and X-ray microanalysis-Importance of epoxy impregnation. Cem. Concr. Res. 2003, 33, 611-616. [CrossRef]

43. Sylvester, P.J. Use of the Mineral Liberation Analyzer (MLA) for Mineralogical Studies of Sediments and Sedimentary Rocks. In Mineralogical Association of Canada Short Course 42; Mineralogical Association of Canada: St. John's, NL, Canada, 2012; pp. 1-16.

44. Layton-Matthews, D.; Hamilton, C.; McClenaghan, M. Mineral Chemistry: Modern Techniques and Applications to Exploration. In Application of Indicator Mineral Methods to Mineral Exploration; McClenaghan, M., Plouffe, A., Layton-Matthews, D., Eds.; Open File 7553; Geological Survey of Canada: Ottawa, ON, Canada, 2014; pp. 9-18. 
45. Sandmann, D. Method Development in Automated Mineralogy. Ph.D. Thesis, Technischen Universität Bergakademie Freiberg, Freiberg, Germany, 2015.

46. Simandl, G.J.; Mackay, D.A.R.; Ma, X.; Luck, P.; Gravel, J.; Grcic, B.; Redfearn, M. Direct and Indirect Indicator Minerals in Exploration for Carbonatite and Related Ore Deposits-An Orientation Survey, British Columbia, Canada. In Proceedings of the 27th International Applied Geochemistry Symposium, Tucson, AZ, USA, 20-24 April 2015; pp. 33-39.

47. Hulkki, H.; Taivalkoski, A.; Lehtonen, M. Signatures of $\mathrm{Cu}(-\mathrm{Au})$ mineralisation reflected in inorganic and heavy mineral stream sediments at Vähäkurkkio, north-western Finland. J. Geochem. Explor. 2018, 188, 156-171. [CrossRef]

48. Dreimanis, A.; Vagners, U. Bimodal Distribution of Rock and Mineral Fragments in Basal Tills. In Till, a Symposium; Goldthwaite, R.P., Ed.; Ohio State University Press: Columbus, OH, USA, 1971; pp. 237-250.

49. Pickett, J. Method Development for the Systematic Separation of the $<63 \mu \mathrm{m}$ Heavy Mineral Fraction from Bulk Till Samples. Master's Thesis, Queen's University, Kingston, ON, Canada, 2018.

50. Lougheed, H.D.; McClenaghan, M.B.; Layton-Matthews, D. Mineral Markers of Base Metal Mineralization: Progress Report on the Identification of Indicator Minerals in the Fine Heavy Mineral Fraction. In Targeted Geoscience Initiative: 2017 Report of Activities; Rogers, N., Ed.; Open File 8373; Geological Survey of Canada: Ottawa, ON, Canada, 2018; Volume 2, pp. 101-108.

51. Day, S.J.A.; Lariviere, J.M.; McNeil, R.J.; Friske, P.W.B.; Cairns, S.R.; McCurdy, M.W.; Wilson, R.S. Regional Stream Sediment and Water Geochemical Data, Horn Playeau area, Northwest Territories (Parts of NTS 85E, 85F, 85K, 85L, 95H, 95I and 95J) Including Analytical, Mineralogical, and Kimberlite Indicator Mineral Data; Open File 5478; Geological Survey of Canada: Ottawa, ON, Canada, 2007.

52. Falck, H.; Day, S.; Pierce, K.L.; Cairns, S.R.; Watson, D. Geochemical, Mineralogical and Indicator Mineral Data for Stream Silt Sediment, Heavy Mineral Concentrates and Waters, Flat River area, Northwest Territories, (Part of NTS 95E, 105H and 105I); NWT Open Report 2015-002; Northwest Territories Geoscience Office: Yellowknife, NT, Canada, 2015.

53. Lastra, R.; Petruk, W. Mineralogical characterization of sieved and un-sieved samples. J. Miner. Mater. Charact. Eng. 2014, 2, 40-48. [CrossRef]

54. Voordouw, R.J.; Gutzmer, J.; Beukes, N.J. Zoning of platinum group mineral assemblages in the UG2 chromitite determined through in situ SEM-EDS-based image analysis. Miner. Depos. 2010, 45, 147-159. [CrossRef]

55. Berlin, J. Analysis of boron with energy dispersive X-ray spectrometry. Imaging Microsc. 2011, 13, $19-21$.

56. McClenaghan, M.B.; Hicken, A.; Paulen, R.; Layton-Matthews, D. Indicator Mineral Counts for Regional till Samples Around the Izok Lake $\mathrm{Zn}-\mathrm{Cu}-\mathrm{Pb}-\mathrm{Ag}$ VMS Deposit, Nunavut; Open File 7029; Geological Survey of Canada: Ottawa, ON, Canada, 2012.

57. Spry, P.G. An unusual gahnite-forming reaction, Geco base-metal deposit, Manitouwadge, Ontario. Can. Mineral. 1982, 20, 549-553.

58. Theart, H.; Ghavami-Riabi, R.; Mouri, H.; Gräser, P. Applying the box plot to the recognition of footwall alteration zones related to VMS deposits in a high-grade metamorphic terrain, South Africa, a lithogeochemical exploration application. Geochemistry 2011, 71, 143-154. [CrossRef]

59. Bonnet, A.; Corriveau, L. Alteration Vectors to Metamorphosed Hydrothermal Systems in Gneissic terranes. In Mineral Deposits of Canada: A Synthesis of Major Deposit-Types, District Metallogeny, the Evolution of Geological Provinces, and Exploration Methods; Goodfellow, W., Ed.; Geological Association of Canada: St. John's, NL, Canada, 2007; Volume 5, pp. 141-161.

60. Zaleski, E.; Froese, E.; Gordon, T.M. Metamorphic petrology of Fe-Zn-Mg-Al alteration at the Linda volcanogenic massive sulfide deposit, Snow Lake, Manitoba. Can. Mineral. 1991, 29, 995-1017.

61. Stoddard, E.F. Zinc-rich hercynite in high-grade metamorphic rocks; a product of the dehydration of staurolite. Am. Mineral. 1979, 64, 736-741.

62. Dietvorst, E.J. Biotite breakdown and the formation of gahnite in metapelitic rocks from Kemiö, Southwest Finland. Contrib. Mineral. Petrol. 1981, 75, 327-337. [CrossRef]

63. Spry, P.G.; Scott, S.D. The stability of zincian spinels in sulfide systems and their potential as exploration guides for metamorphosed massive sulfide deposits. Econ. Geol. 1986, 81, 1446-1463. [CrossRef]

64. Ghosh, B.; Praveen, M. Indicator minerals as guides to base metal sulphide mineralisation in Betul Belt, central India. J. Earth Syst. Sci. 2008, 117, 521-536. [CrossRef] 
65. Makvandi, S.; Ghasemzadeh-Barvarz, M.; Beaudoin, G.; Grunsky, E.C.; McClenaghan, M.B.; Duchesne, C. Principal component analysis of magnetite composition from volcanogenic massive sulfide deposits: Case studies from the Izok Lake (Nunavut, Canada) and Halfmile Lake (New Brunswick, Canada) deposits. Ore Geol. Rev. 2016, 72, 60-85. [CrossRef]

66. McClenaghan, M.B.; Budulan, G.; Parkhill, M.A.; Layton-Matthews, D.; Crabtree, D. Indicator Mineral Signatures of the Halfmile Lake $\mathrm{Zn}-\mathrm{Pb}-\mathrm{Cu}$ Volcanogenic Massive Sulphide Deposit, Bathurst, New Brunswick: Part 2-Till Data; Open File 8111; Geological Survey of Canada: Ottawa, ON, Canada, 2016.

67. DiLabio, R. Glacial Dispersal Trains. In Glacial Indicator Tracing; Kujansuu, R., Saarnisto, M., Eds.; August Aimé Balkema: Rotterdam, The Netherlands, 1990; pp. 109-122.

68. Gregory, D.D.; Large, R.R.; Bath, A.B.; Steadman, J.A.; Wu, S.; Danyushevsky, L.; Bull, S.W.; Holden, P.; Ireland, T.R. Trace element content of pyrite from the kapai slate, St. Ives Gold District, Western Australia. Econ. Geol. 2016, 111, 1297-1320. [CrossRef]

69. Mukherjee, I.; Large, R. Application of pyrite trace element chemistry to exploration for SEDEX style Zn-Pb deposits: McArthur Basin, Northern Territory, Australia. Ore Geol. Rev. 2017, 81, 1249-1270. [CrossRef]

70. Harris, D.C.; Cabri, L.J.; Nobiling, R. Silver-bearing chalcopyrite, a principal source of silver in the Izok Lake massive-sulfide deposit; confirmation by electron-and proton-microprobe analyses. Can. Mineral. 1984, 22, 493-498.

71. Hicken, A.; McClenaghan, M.; Paulen, R.; Layton-Matthews, D. Till Geochemical Signatures of the Izok Lake $\mathrm{Zn}-\mathrm{Cu}-\mathrm{Pb}-\mathrm{Ag}$ Volcanogenic Massive Sulphide Deposit; Open File 7046; Geological Survey of Canada: Ottawa, ON, Canada, 2012.

72. McClenaghan, M.; Parkhill, M.; Pronk, A.; Seaman, A.; McCurdy, M.; Leybourne, M. Indicator mineral and geochemical signatures associated with the Sisson W-Mo deposit, New Brunswick, Canada. Geochem. Explor. Environ. Anal. 2017, 17, 297-313. [CrossRef]

(C) 2020 by the authors. Licensee MDPI, Basel, Switzerland. This article is an open access article distributed under the terms and conditions of the Creative Commons Attribution (CC BY) license (http://creativecommons.org/licenses/by/4.0/). 